\title{
THE IMPACT OF URBAN LEGISLATION ON THE SUSTAINABLE URBAN DEVELOPMENT IN EGYPT
}

\author{
Esam Aldin Mohamed Ali \\ Associate Professor, Department of Urban Planning, College \\ of Architecture \& Planning, King Saud University, Riyadh, \\ Kingdom of Saudi Arabia
}

(Received April 18, 2009 Accepted May 27, 2009)

Despite the existence of a vast number of urban legislation in Egypt; it could be a basis for achieving the goals and plans for sustainable urban development, and creating sound urban environments. However, there are many obvious negative manifestations. A closer look to the growth of Egyptian cities shows the slums, which are still prevalent in the growth of these cities. In addition to, the encroachment of urbanization on the agricultural area, as well as the meager use of space, this hinders the process of sustainable urban development.

The research aims to identify the role of urban legislation especially urban planning legislation and local government legislation - in the process of sustainable urban development in the Egyptian cities. Also, the research aims to discover the deficiencies that led to decrease the legislation effectiveness, and show their direct impacts on sustainable urban development.

The research implies five main parts. The first part deals with the introduction, in terms of, the problem, the objectives and methodology of the research. The second part discusses the sustainable urban development in Egypt. The third part emphasizes on the role of urban legislation in sustainable urban development process in Egypt. The fourth part deals with the urban planning legislation in terms of their deficiencies and the most important negative impacts on sustainable urban development. The fifth part discusses the local government legislation in terms of their deficiencies and the most important negative impacts on sustainable urban development.

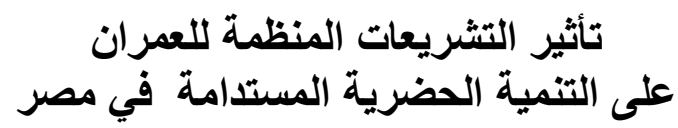

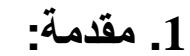

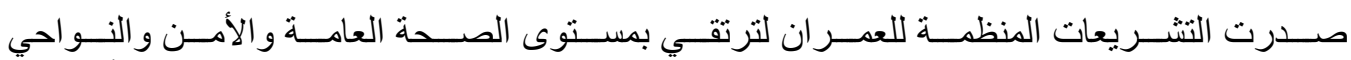

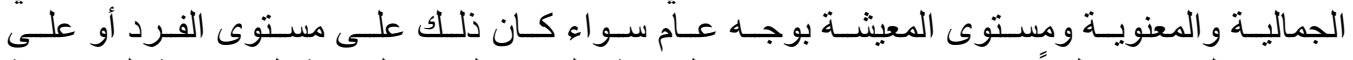

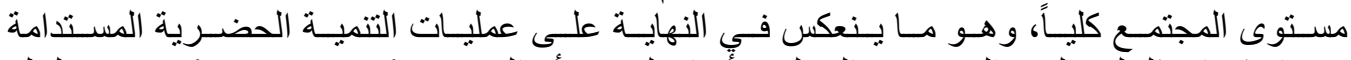

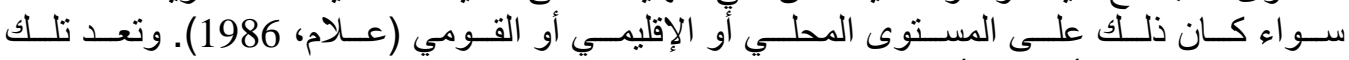

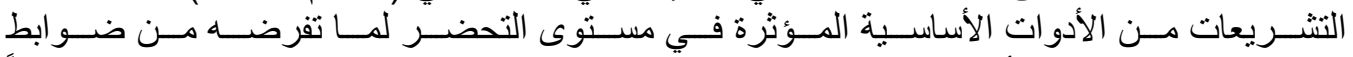

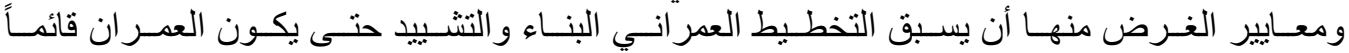




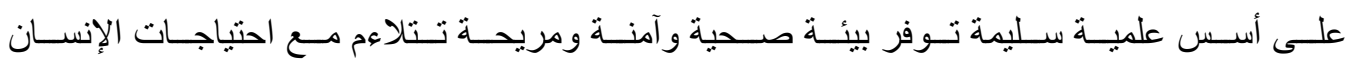

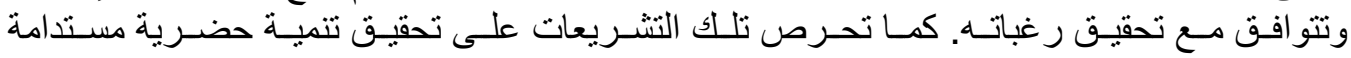

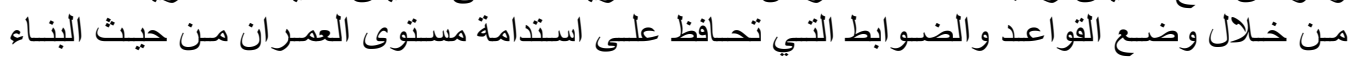
والتثييد و المر افق العامة وغير ها (عبد الئد المعطي، 2000).

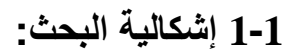

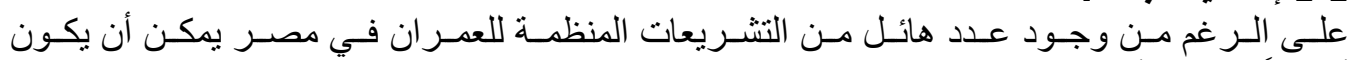

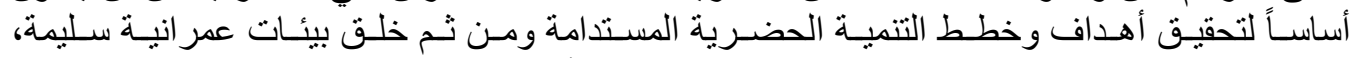

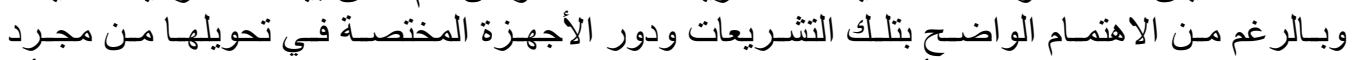

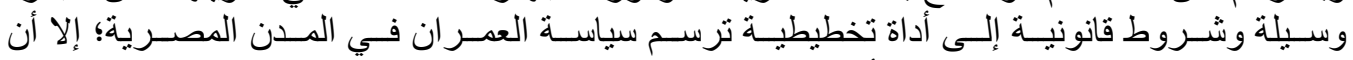

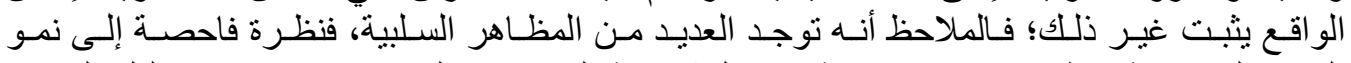

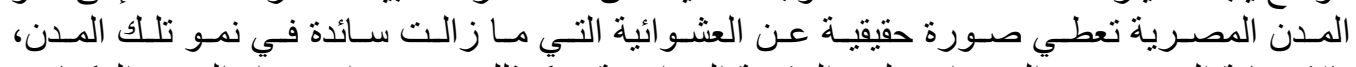

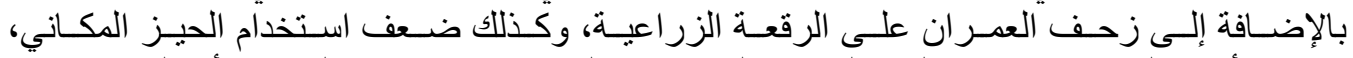

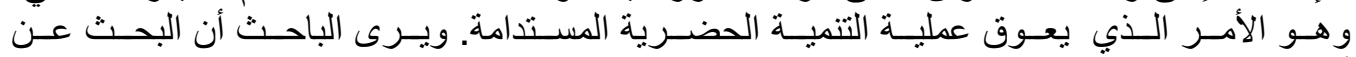

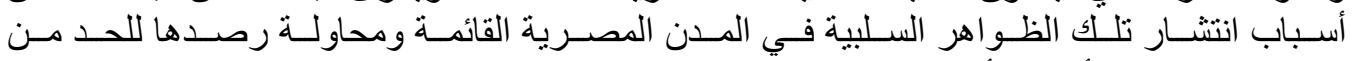

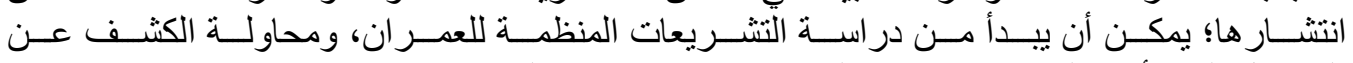

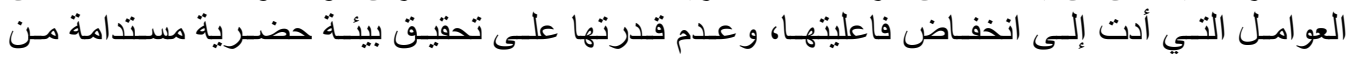
الناحية الوظيفية و الاجتماعية والاقتصادية والجية الجمالية.

2-1 2-1 هدف البحث:

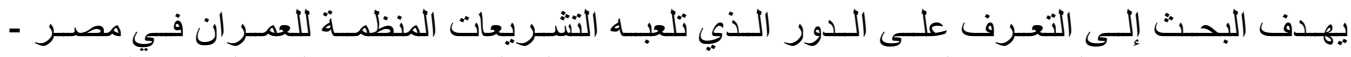

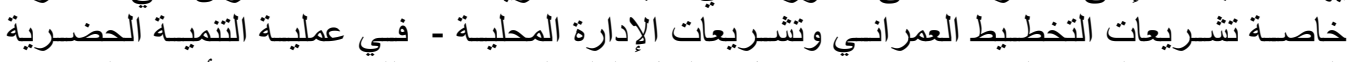

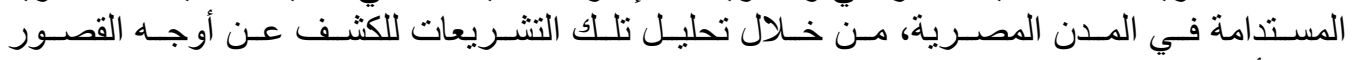

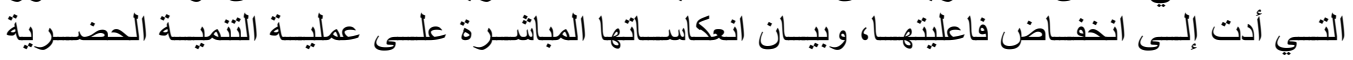

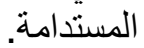

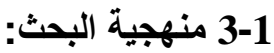

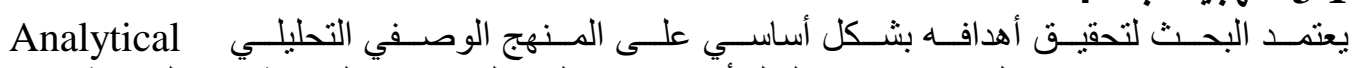
Descriptive

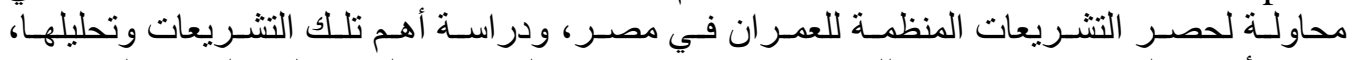

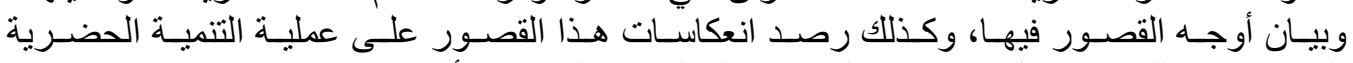

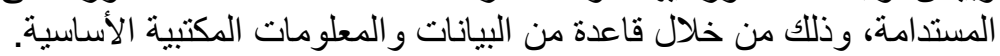

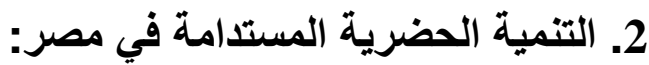

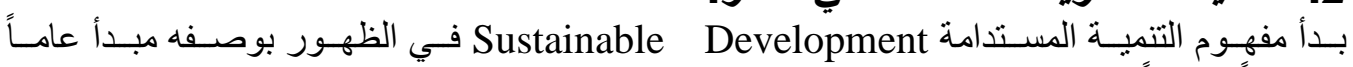

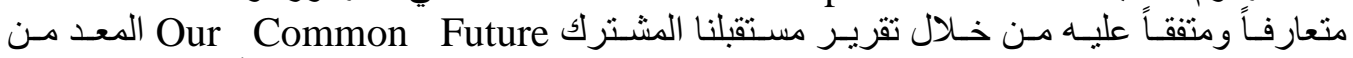

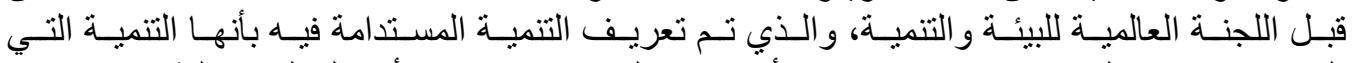

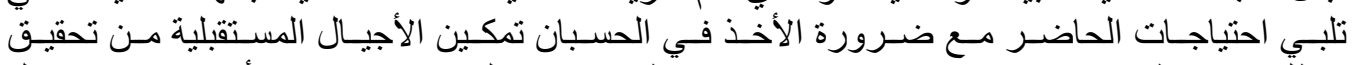

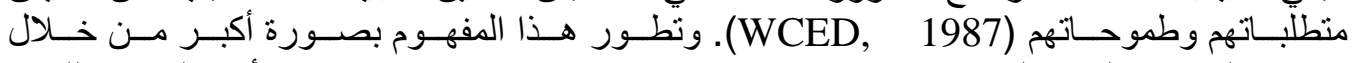

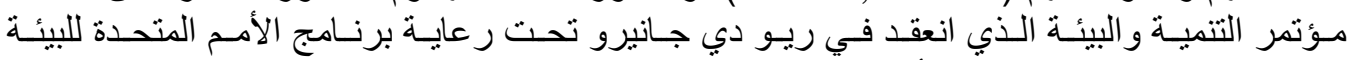

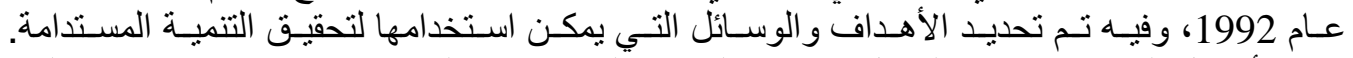

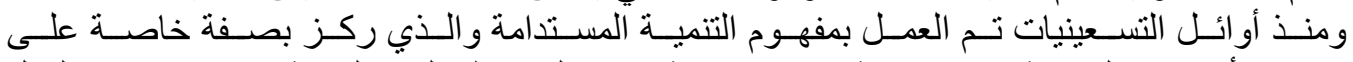

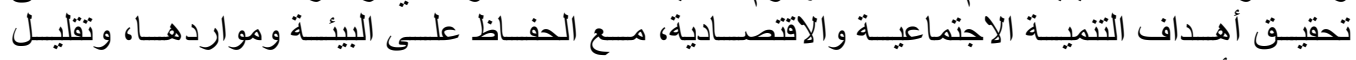

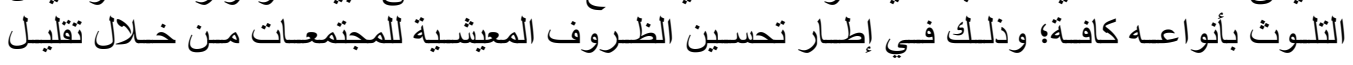




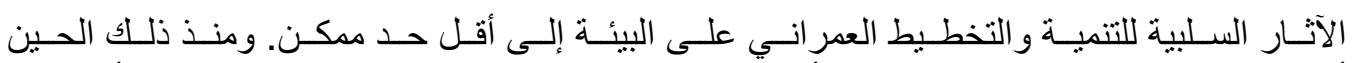

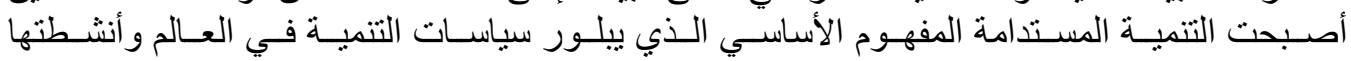

.(Muschett, 1997)

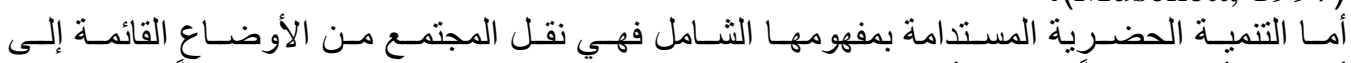

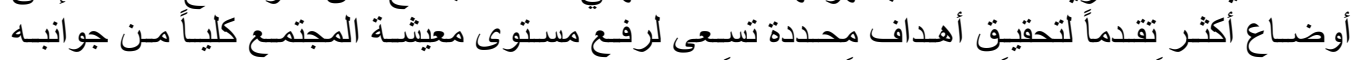

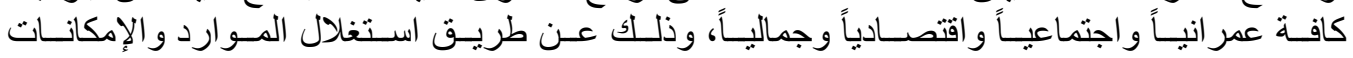

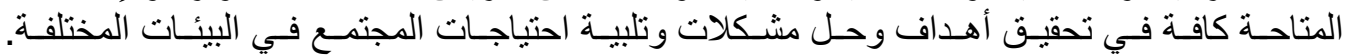

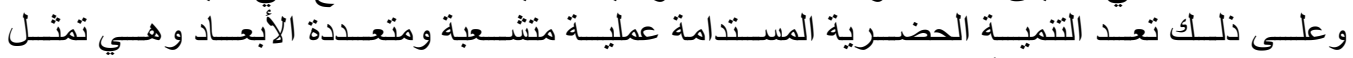

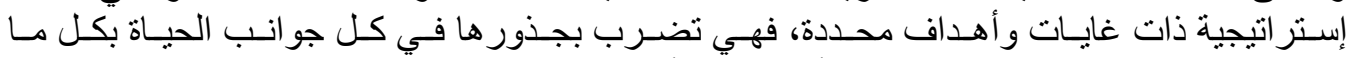

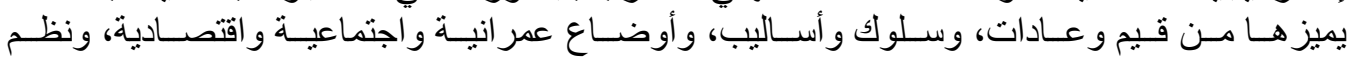

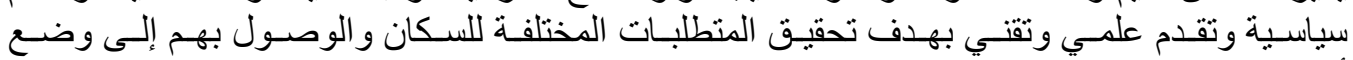
أفضل (Listokin \& Walker, 1989).

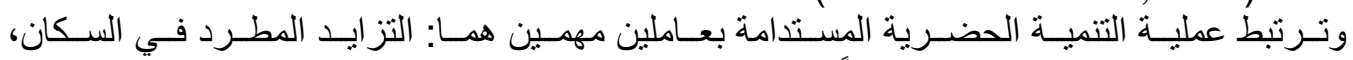

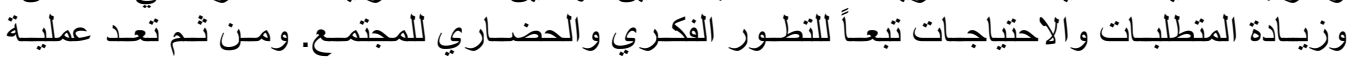

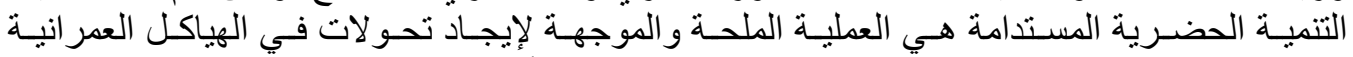

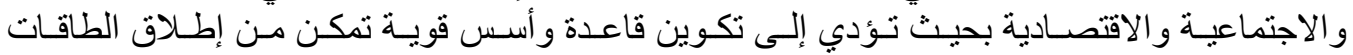

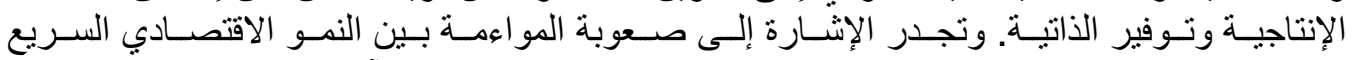

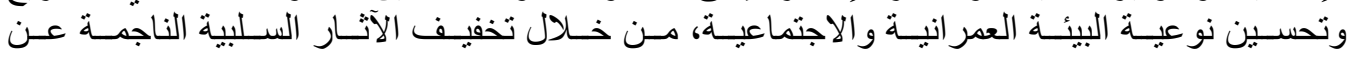

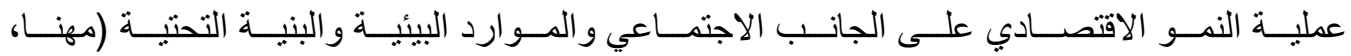

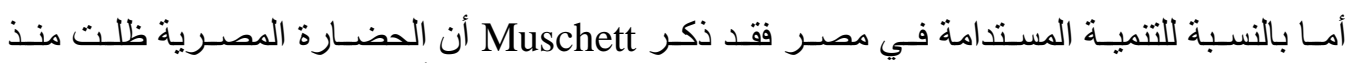

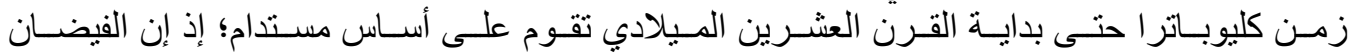

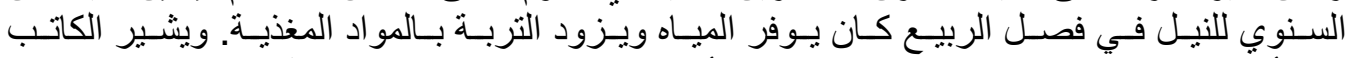

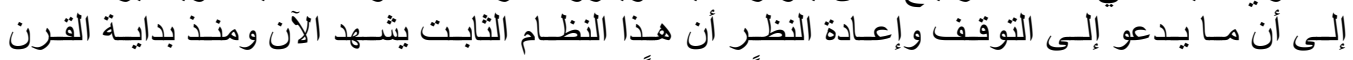

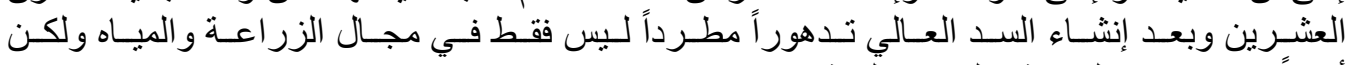

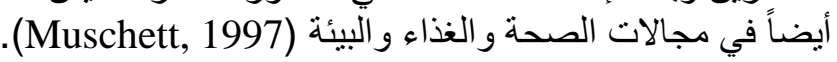

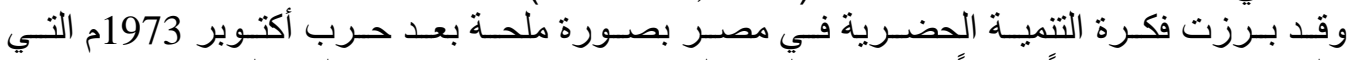

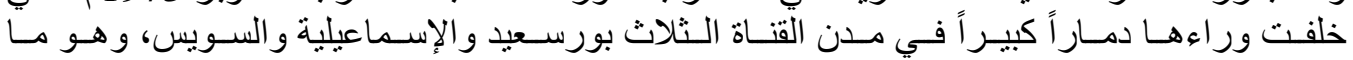

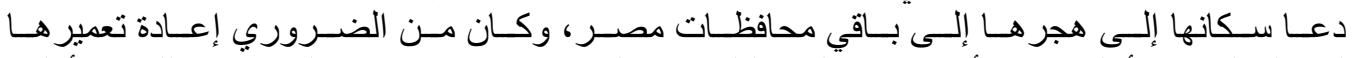

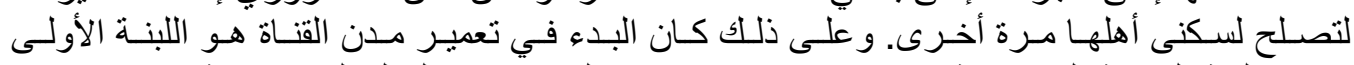

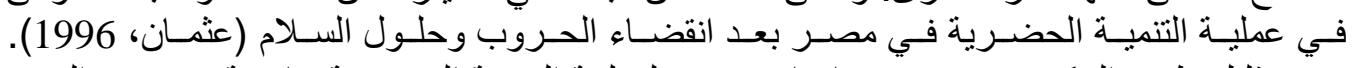

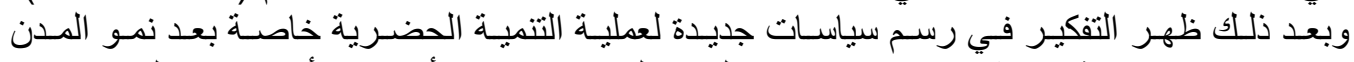

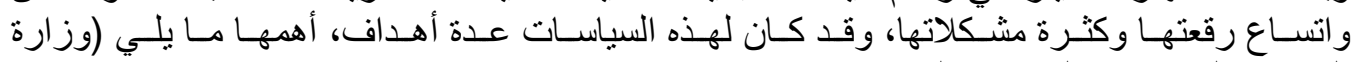

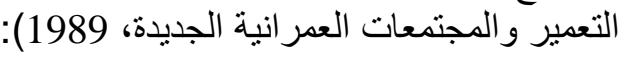

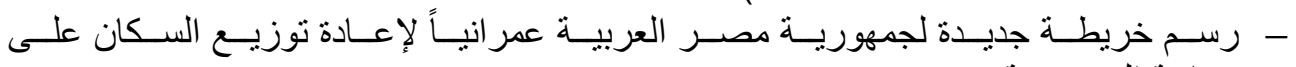
مساحة الجمهورية.

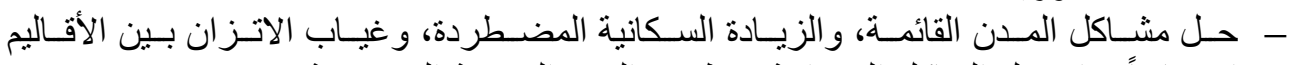

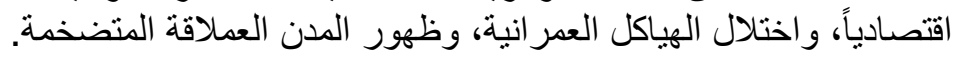

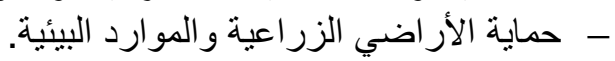

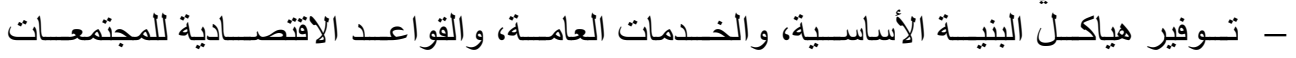
القائمة و الجديدة. 


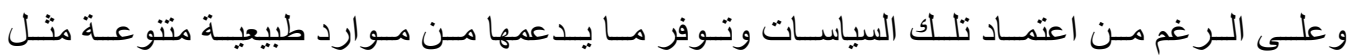

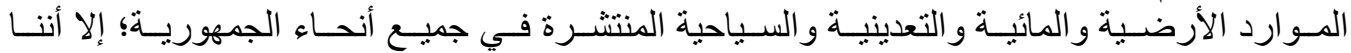

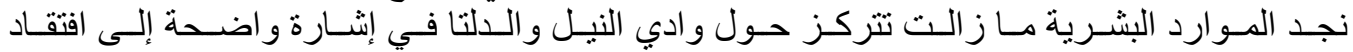

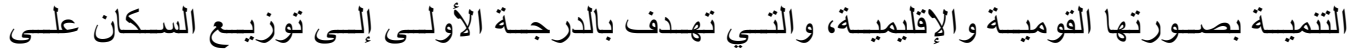

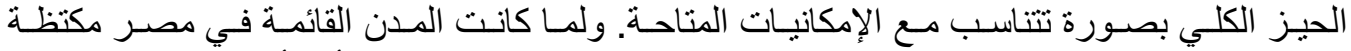

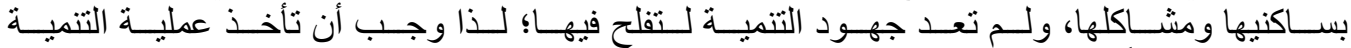

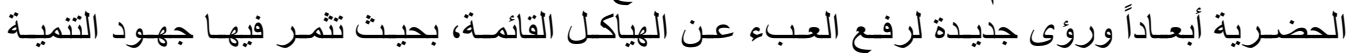

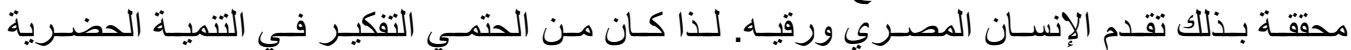

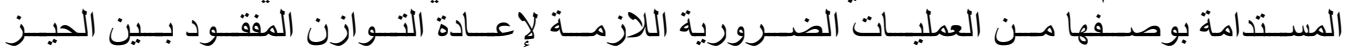

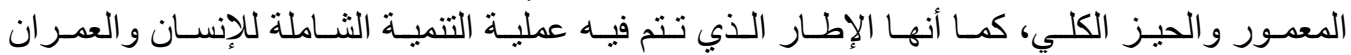
على حدٍ سواء (عثمان، 1996).

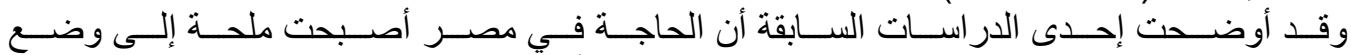

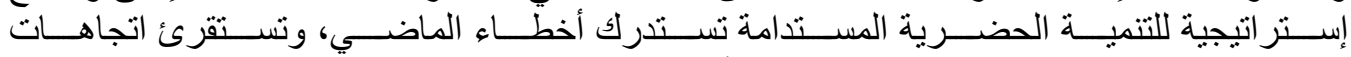

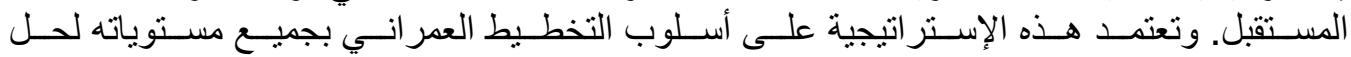

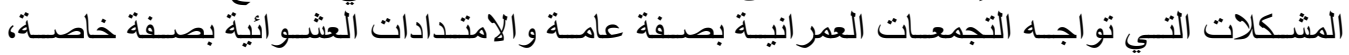

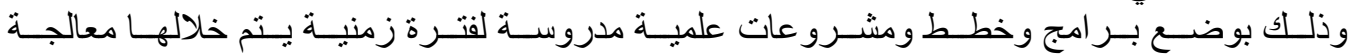

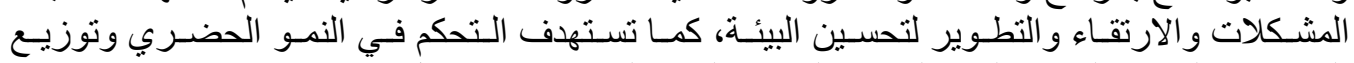
الخدمات و المر افق لتوفير البيئة السكنية الملائمة لحياة المواطن (إسماعيل، 2000).

\section{3. دور التثـــريعات المنظمــة للعمــران بمصـــر فــي عمليــة التنميــة العضــرية}

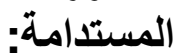

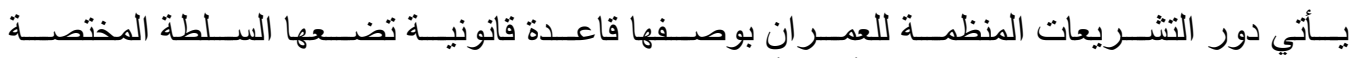

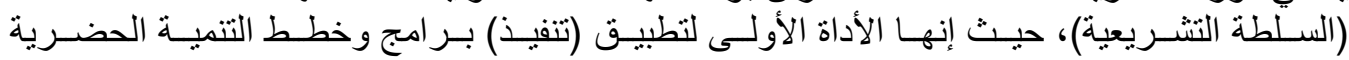

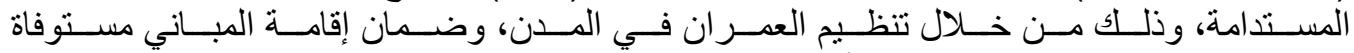

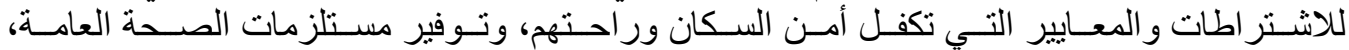

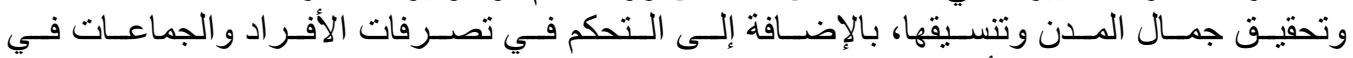

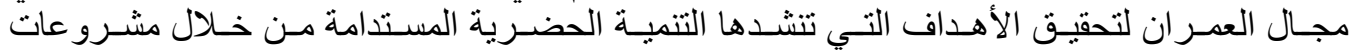

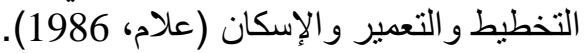

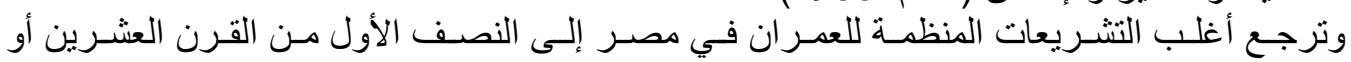

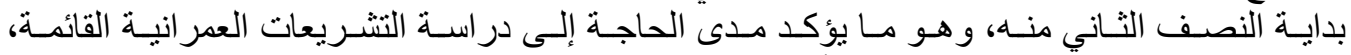

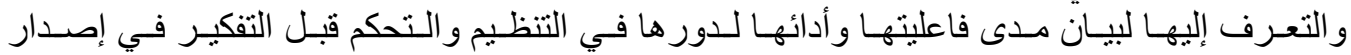
تشريعات جديدة (Ali, 1998). 


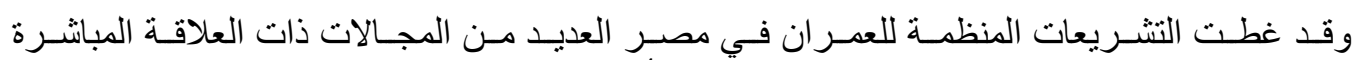
بالتنمية الحضرية المستدامة، ومن أهمات الهم تللك التشريعات 1 ما فا يلي:

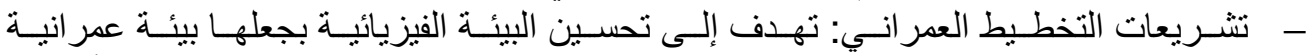

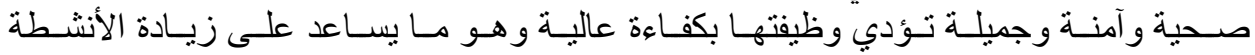

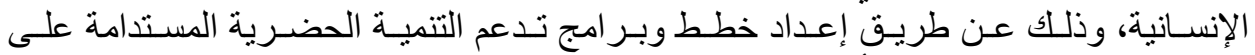

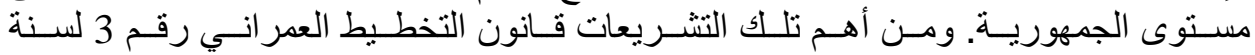

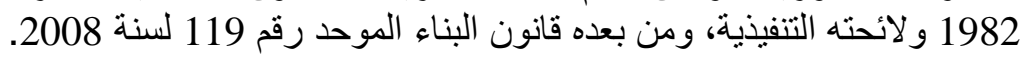

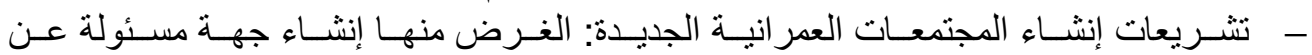

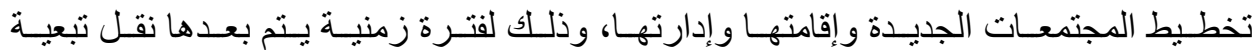

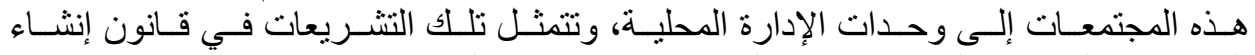
المجتمعات العمر انية الجديدة رقم 59 لسنة 1979 و لائحته التنفيذية.

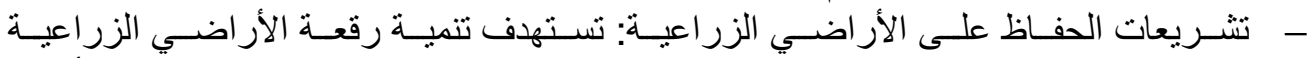

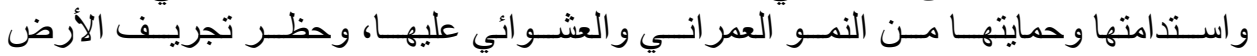

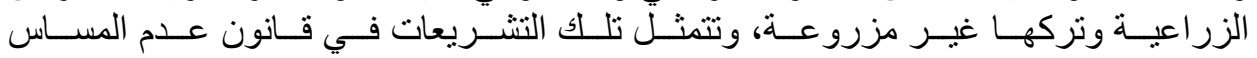

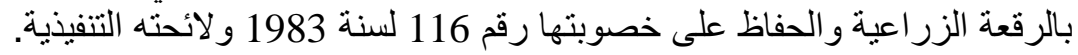

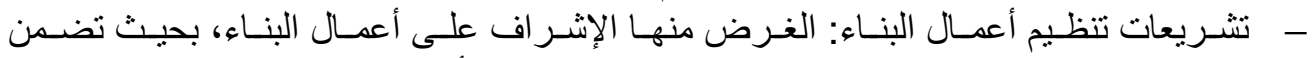

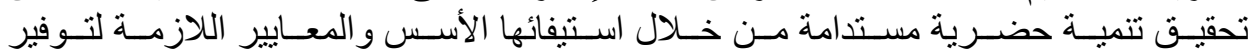

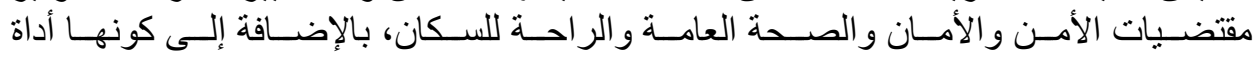

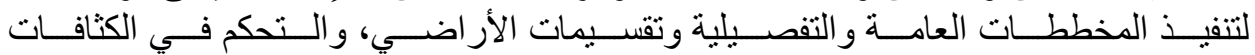

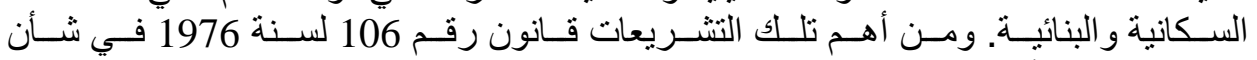

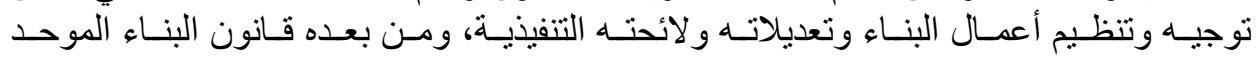
رقم 119 لسنة 2008.

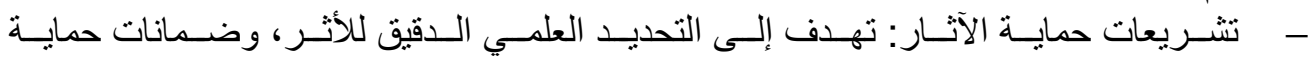

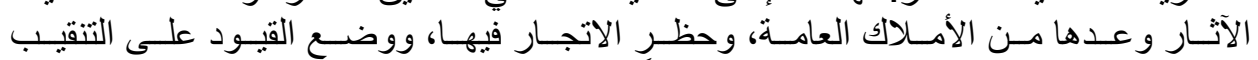

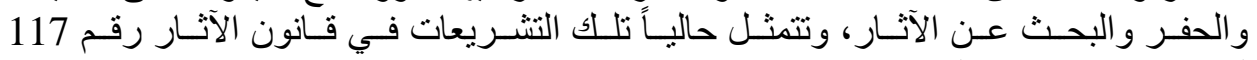
لسنة 1983 و لائحته التنفيذية.

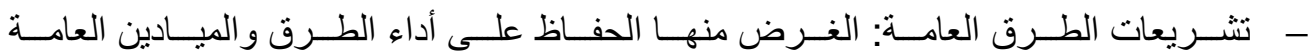

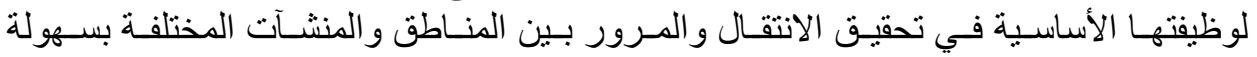

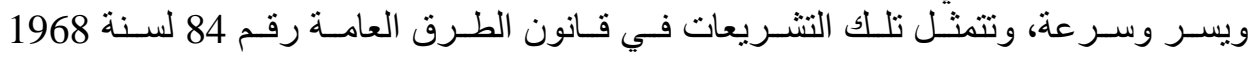
و لائحته التنفيذية.

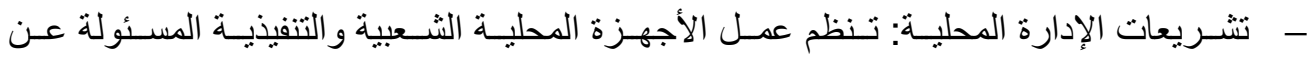

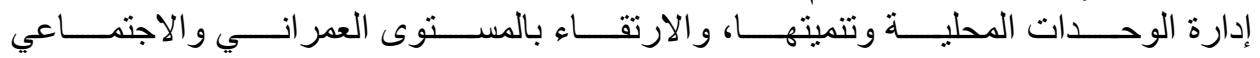

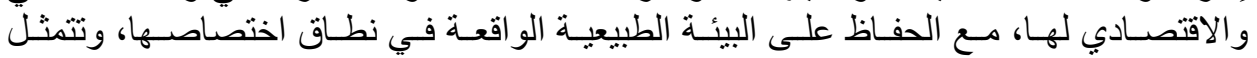

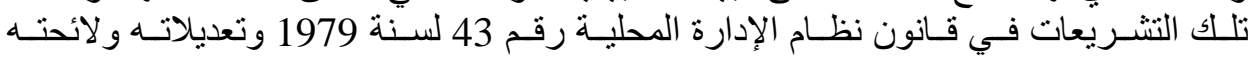

التنفيذية.

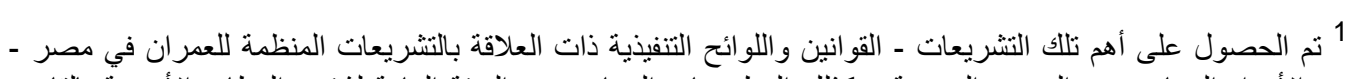

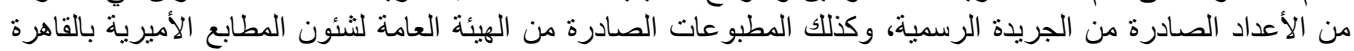
على مر السنوات الماضية. 


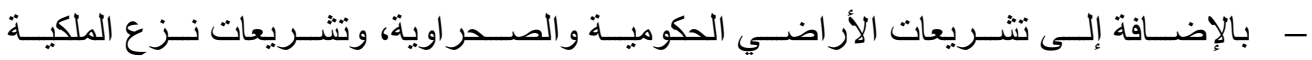

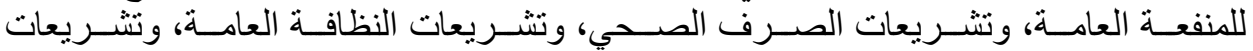

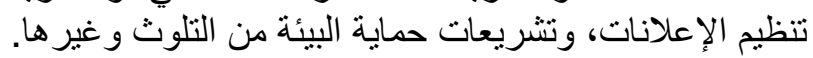

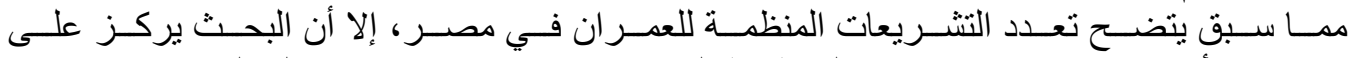

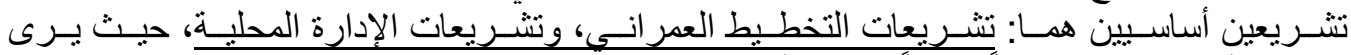

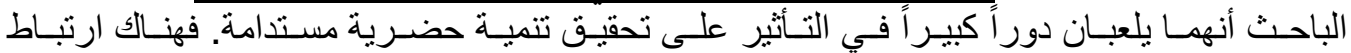

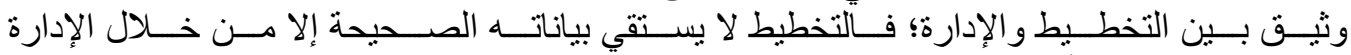

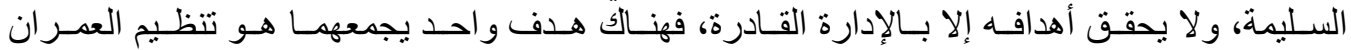

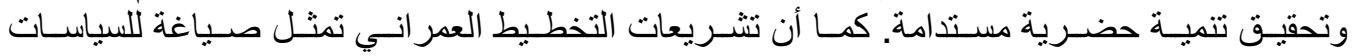

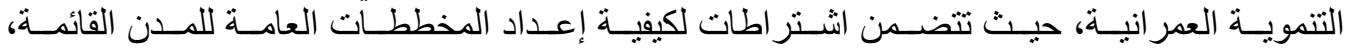

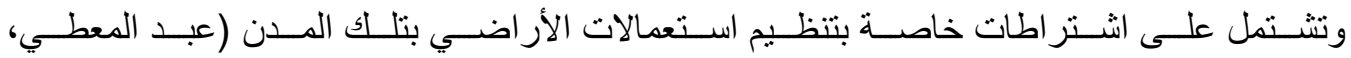
. (2000

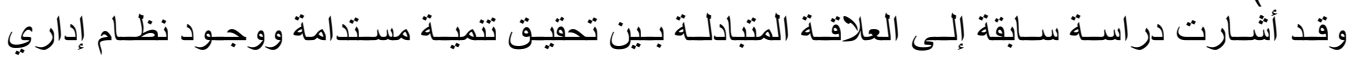

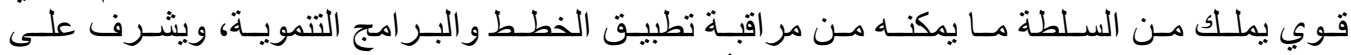

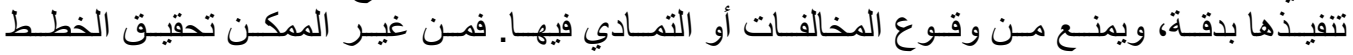

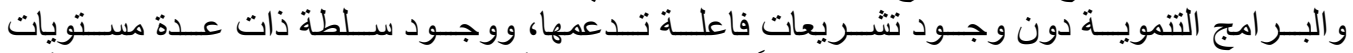

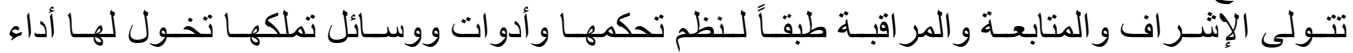

عملها بكفاءة (Zeijl-Rozema and Others, 2008).

\section{4. تأثير تشريعات التخطيط العمراني على التنمية الحضرية المستدامة:}

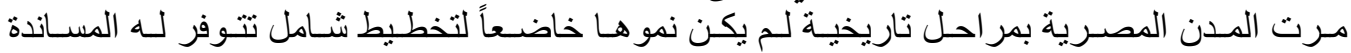

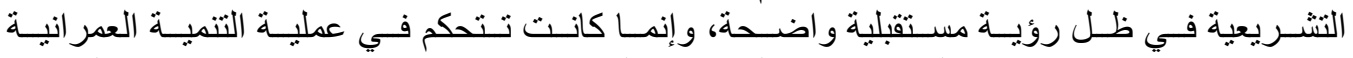

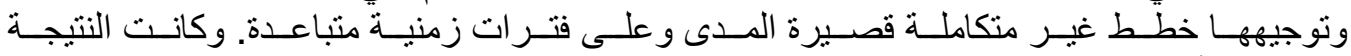

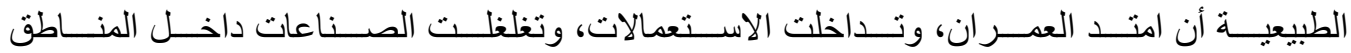

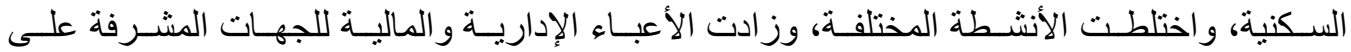

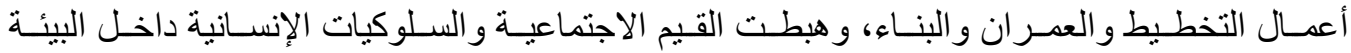

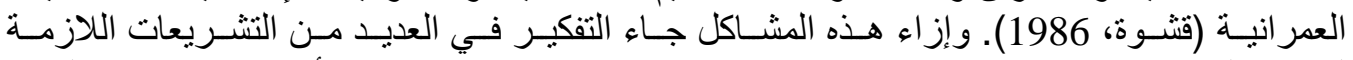

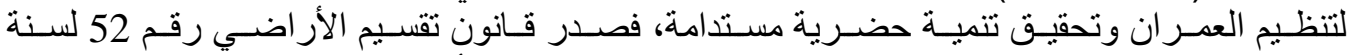

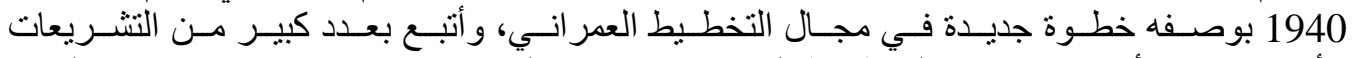

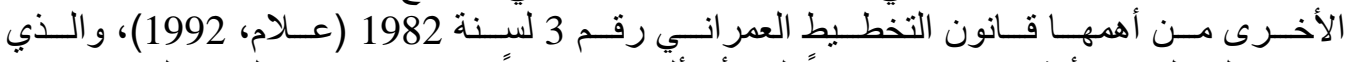

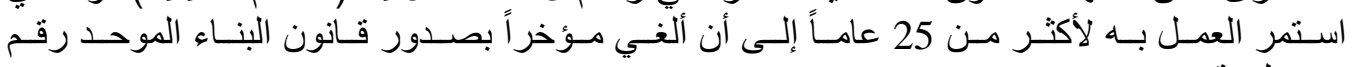

119 لسنة 119

1-4 فاعلية تشريعات التخطيط العمراني:

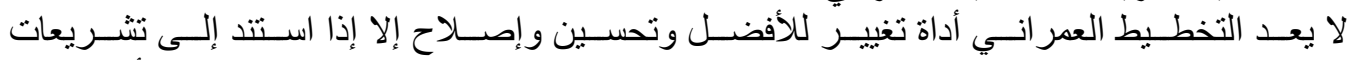

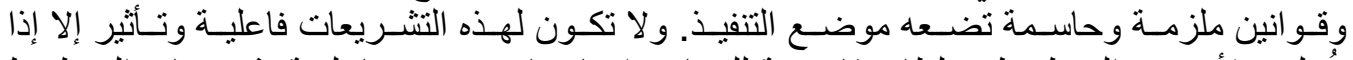

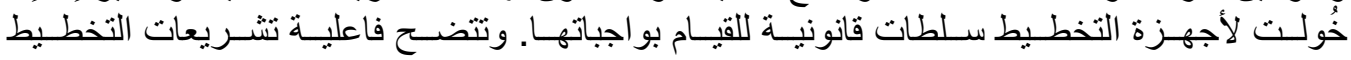

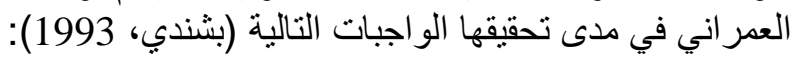

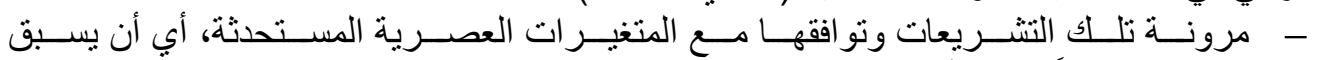

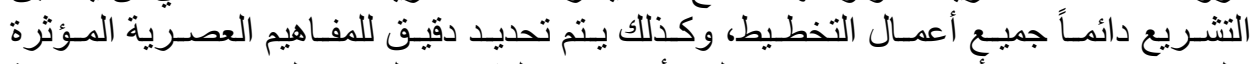

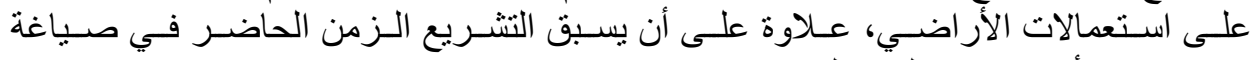
استعمالات الأر اضي في المستقبل. الأسي 


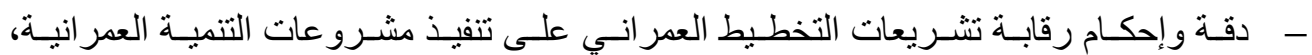

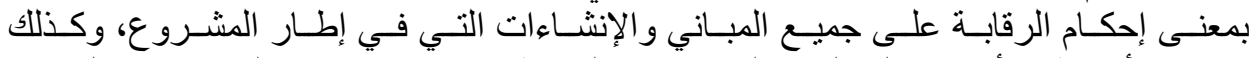

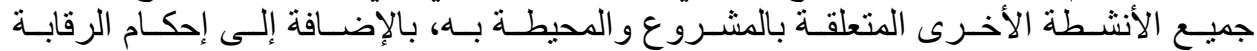

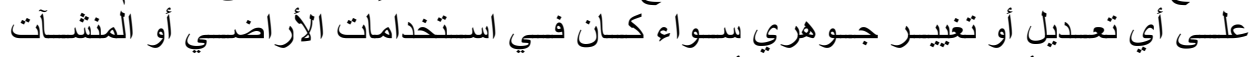

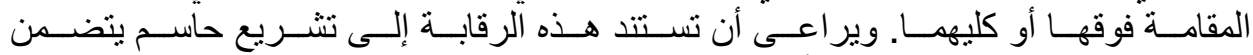

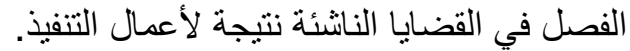

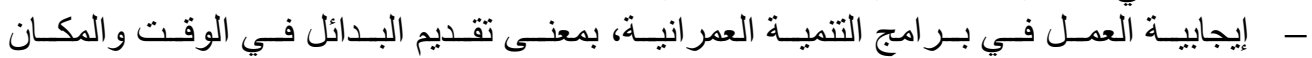

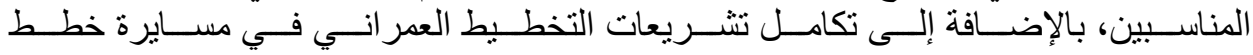
ومشرو عات التنمية الحضرية المستدامة.

2-4 الجهات المسئولة عن التخطيط العمراني في مصر:

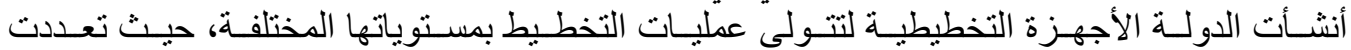

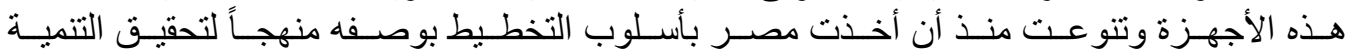
الثـاملة. وقـد تطـورت تلكـ الأجهـزة منـذ ثـورة يوليـو 1952 وحتـى الآن ومـرت بمر احـل مختلفـة،

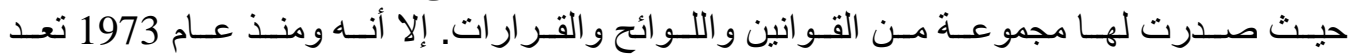

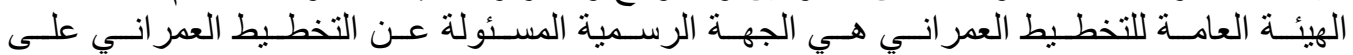

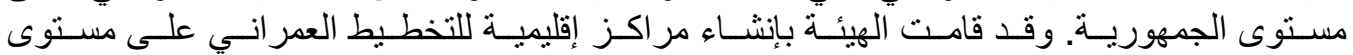

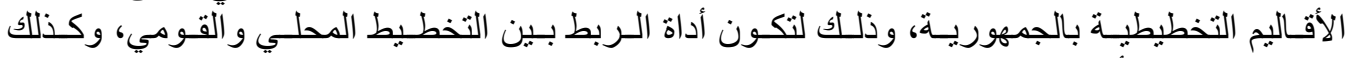

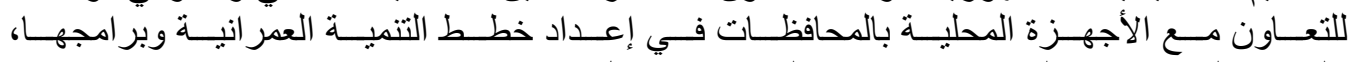

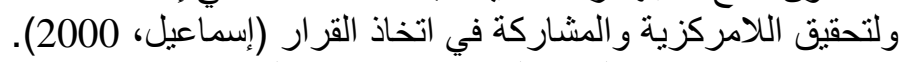

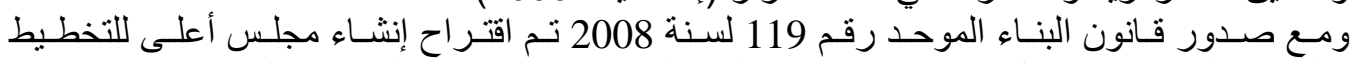

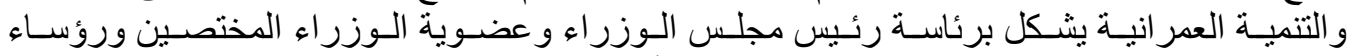

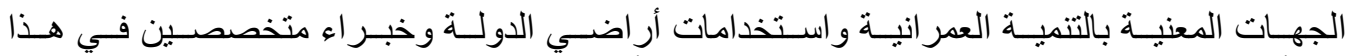

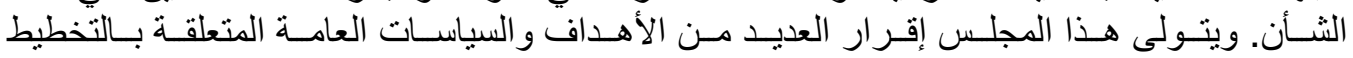

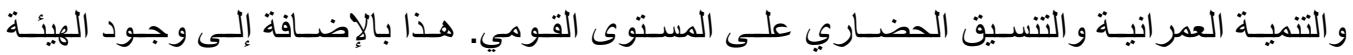

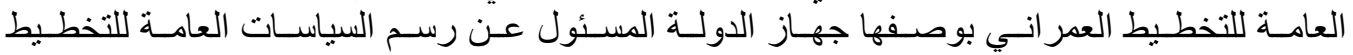

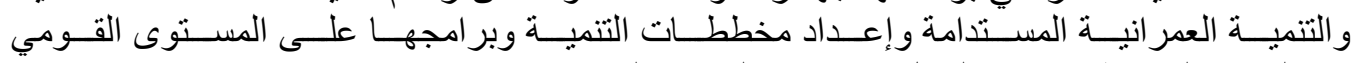
و الإقليمي و المحافظة، راجع الثكل رقم (1) (الجريدة الرسمية، 2008).

\section{3-4 قانون التخطيط العمراني رقم 3 لسنة 1982:}

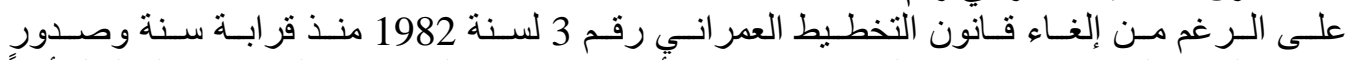

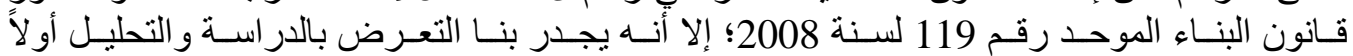

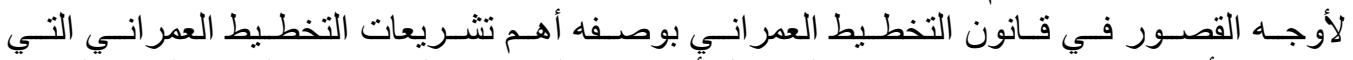

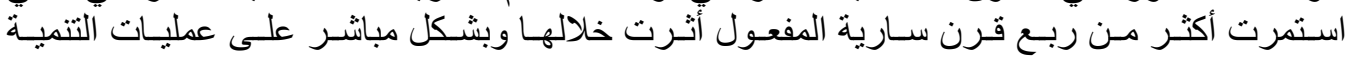

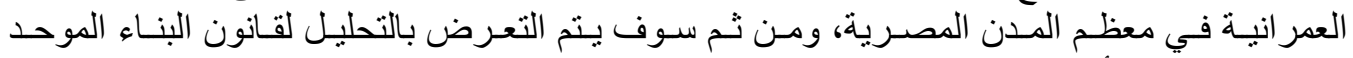
من حيث تغطيّته لأوجه القصور في القانون السابق من عدمه. 


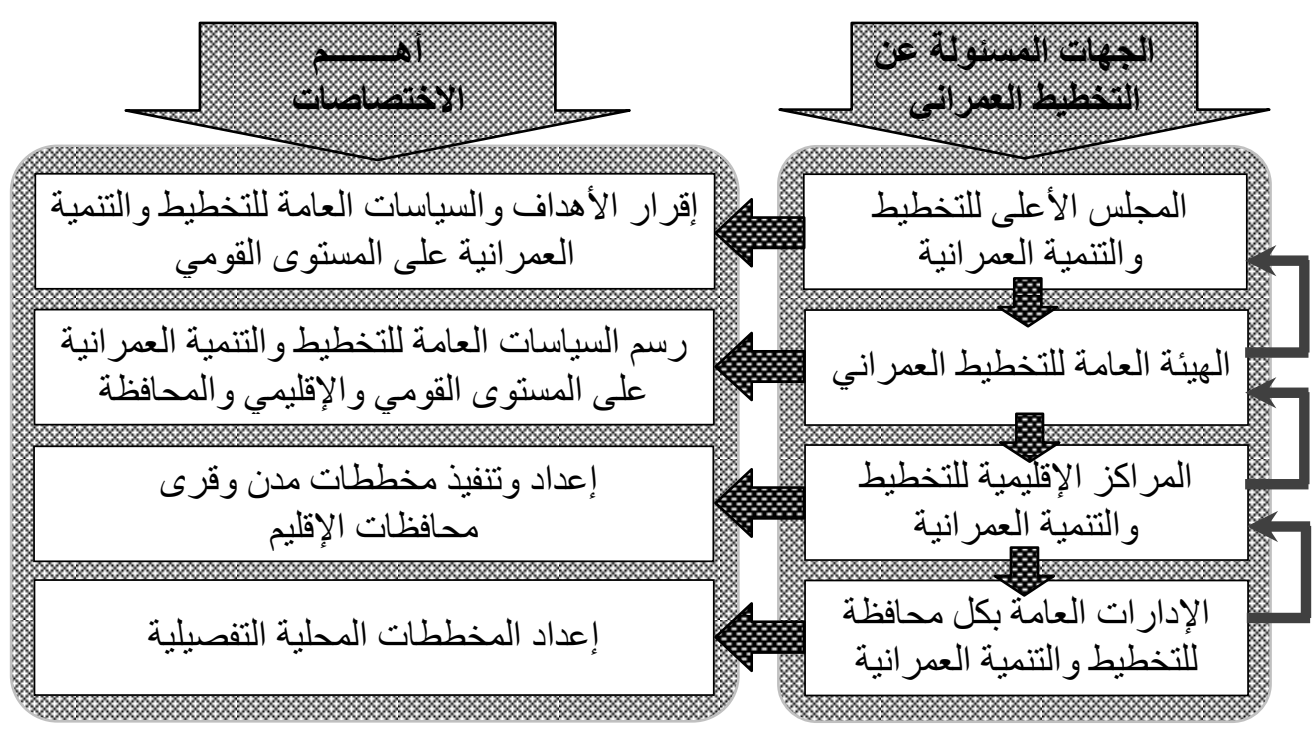

الثكل رقم (1) الجهات المسئولة عن التخطبط العمر اني في مصر طبقاً لمستو ياتها و أهم اختصاصاتها (الجريدة الرسمية، النة 2008 بتصرف من الباحث).

\section{1-3-4 أوجه القصور في قانون التخطيط العمراني رقم 3 لسنة 1982:}

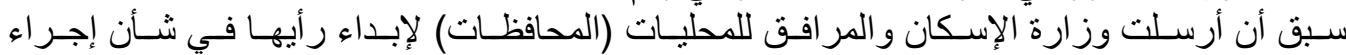

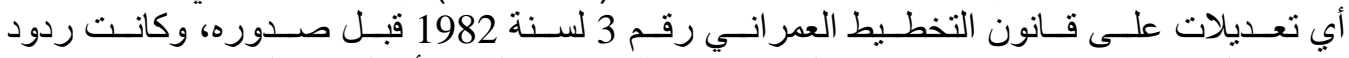

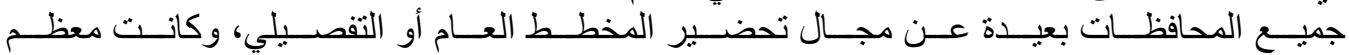

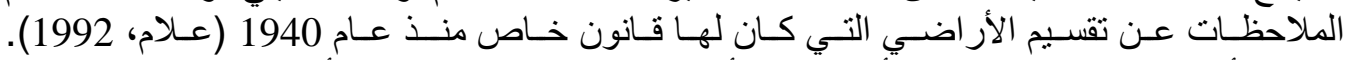

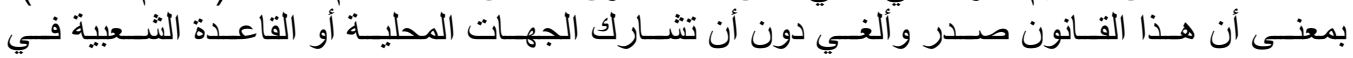

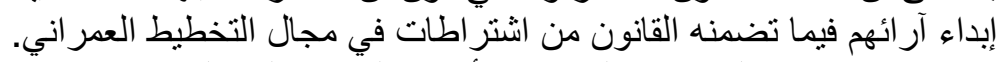

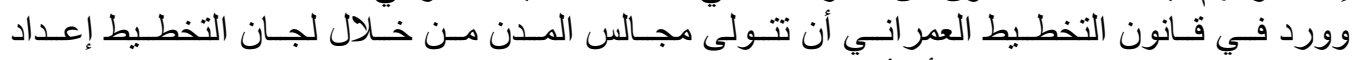

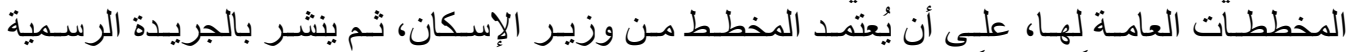

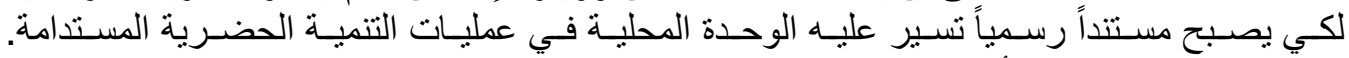

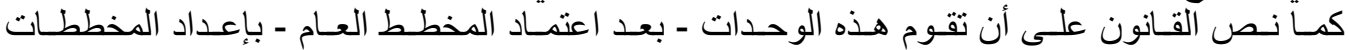

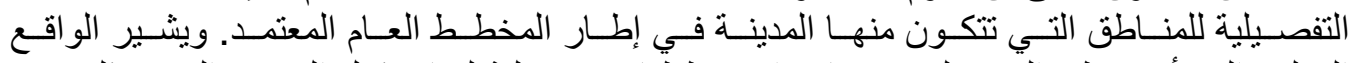

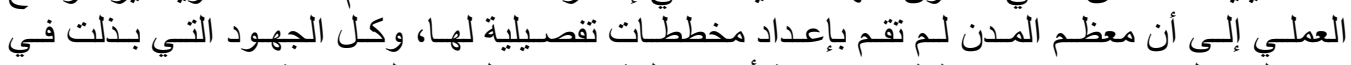

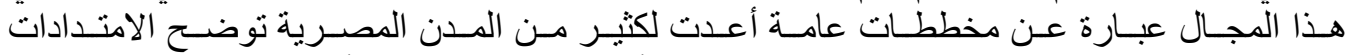

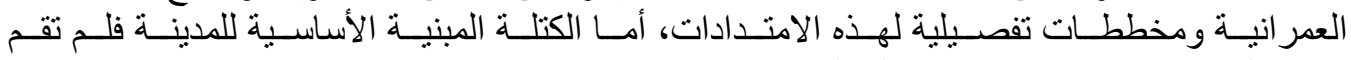
معظم المدن بإعداد مخططات تفصيلية لها (Ali, 1998).

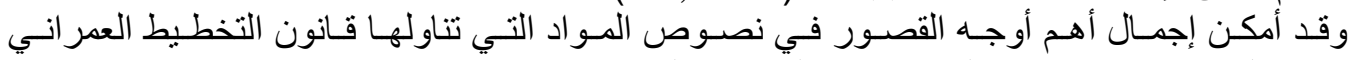
رقم 3 لسنة 1982 و لائحته التنفيذية فيما يلي (عبد الفي الرحمن، 1996):

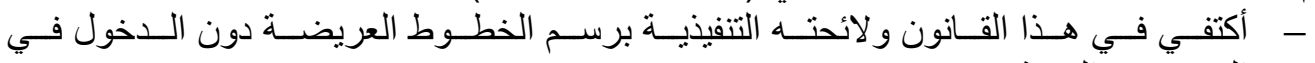
التفصيلات الدقيقة.

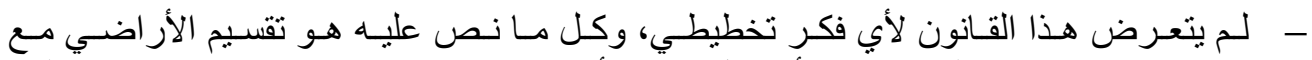

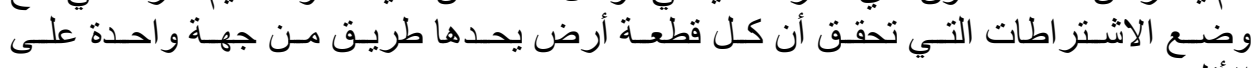




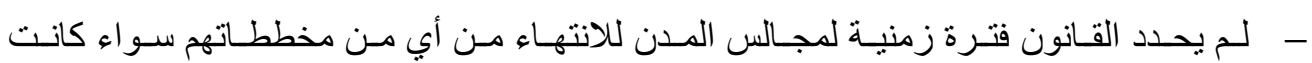
العامة أو التفصيلية.

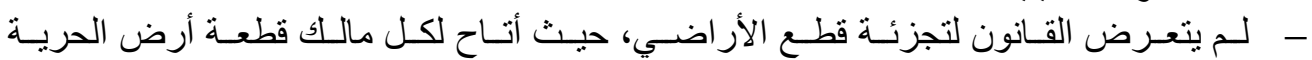

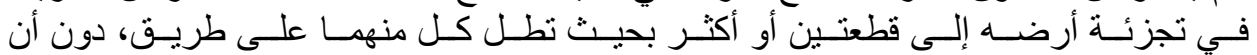

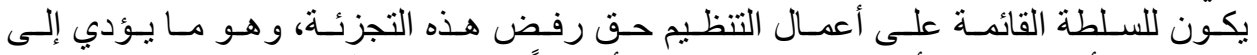
وجود قطع أر اضي ذات أبعاد غير منتاسبة تنتج أحجاماً مشوهة هن من المباني.

2-3-4 انعكاس القصور في قانون التخطيط العمراني على التنمية الحضرية المستدامة:

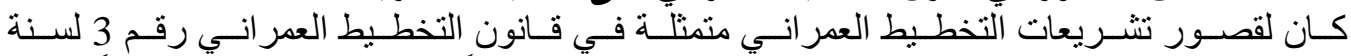

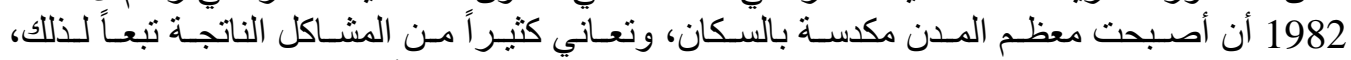

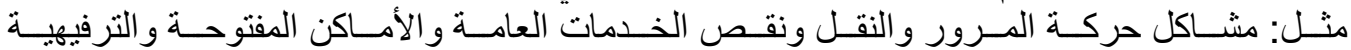

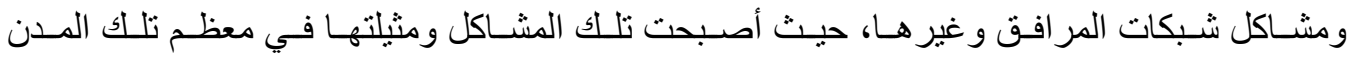

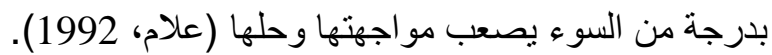

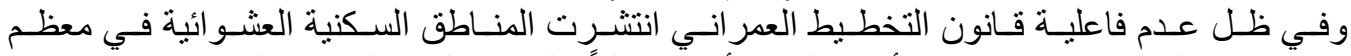

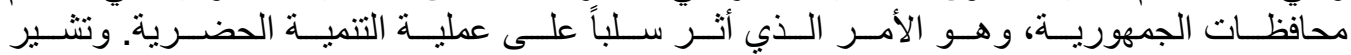

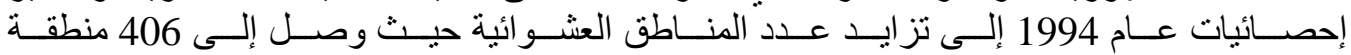

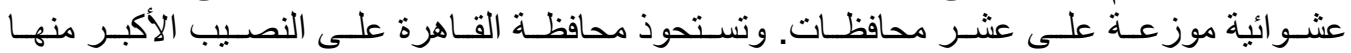

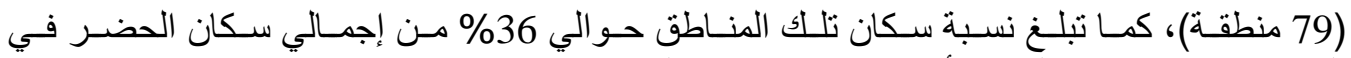

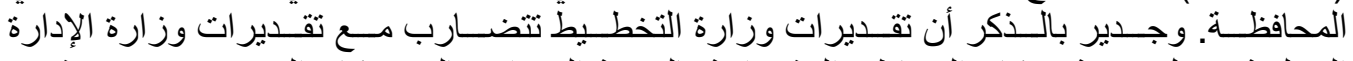

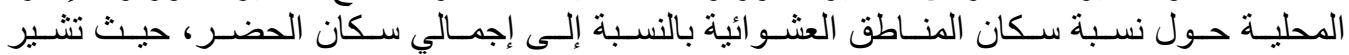

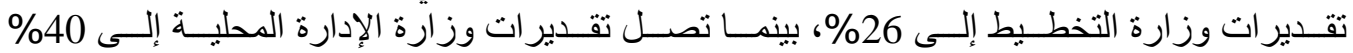

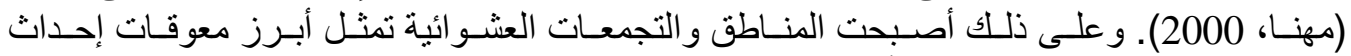

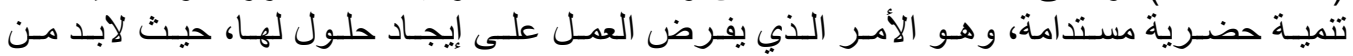

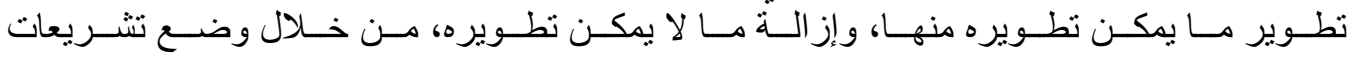

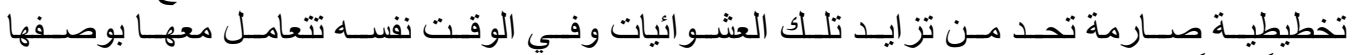

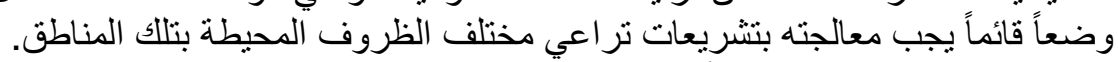

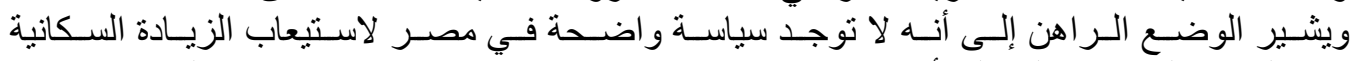

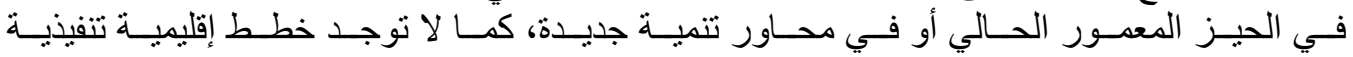

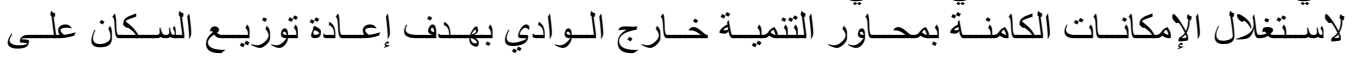

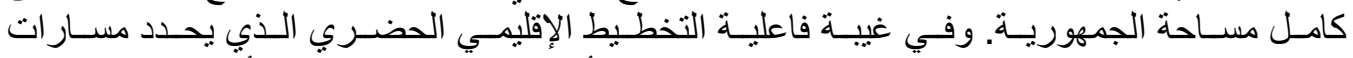

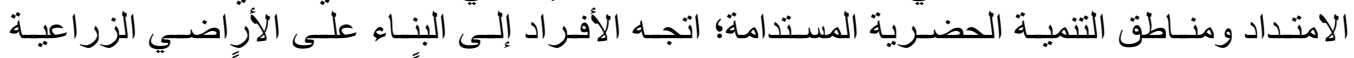

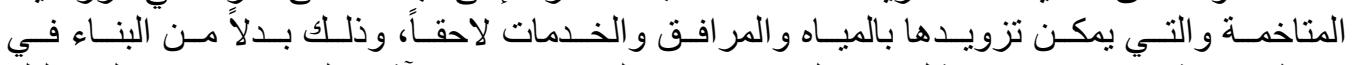

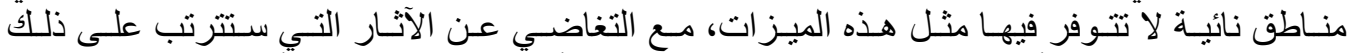

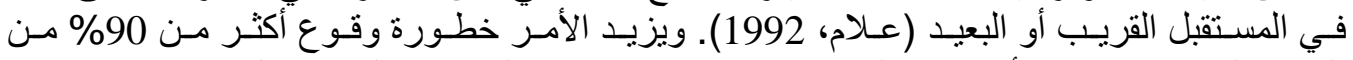

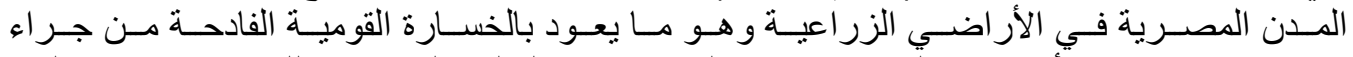

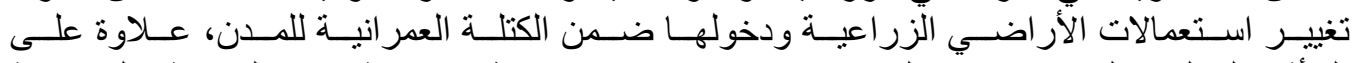

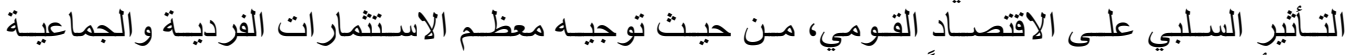

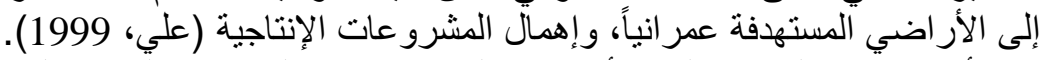

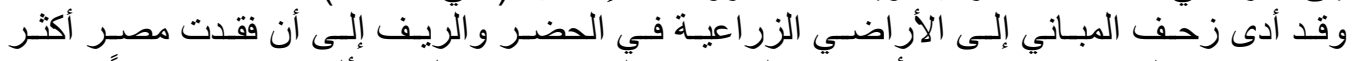

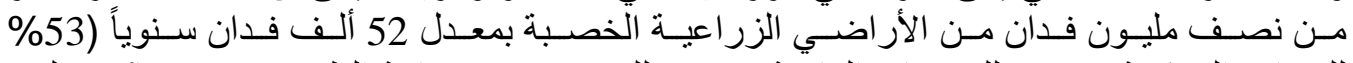

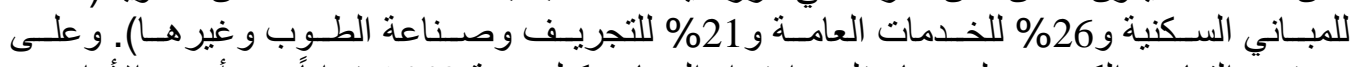

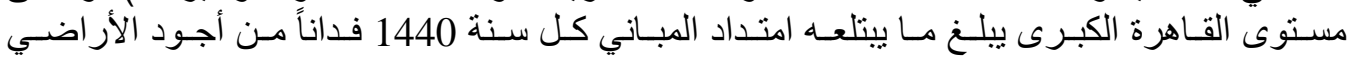




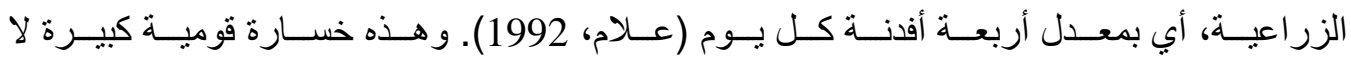

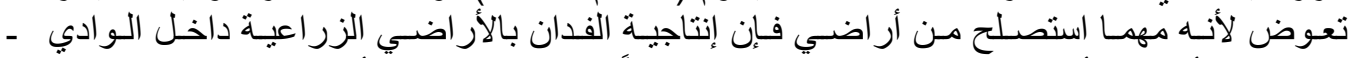

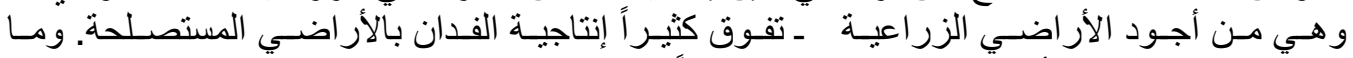

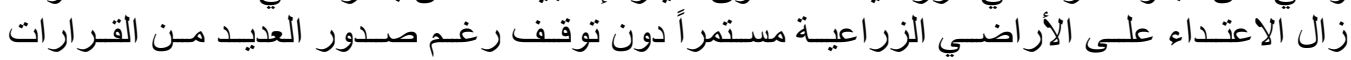

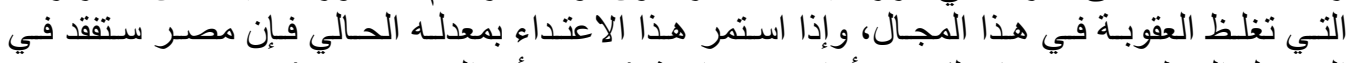

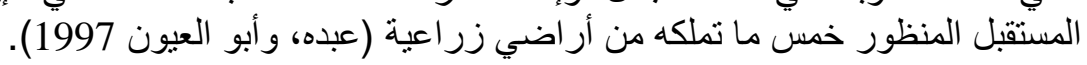

\section{4-4 قانون البناء الموحد رقم 119 لسنة 2008:}

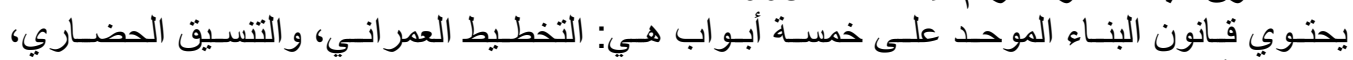

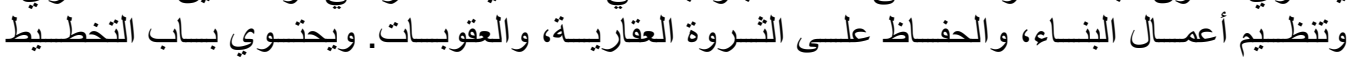

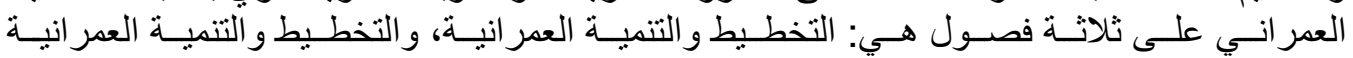

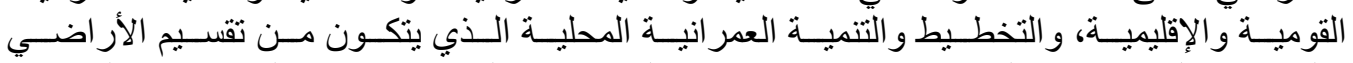

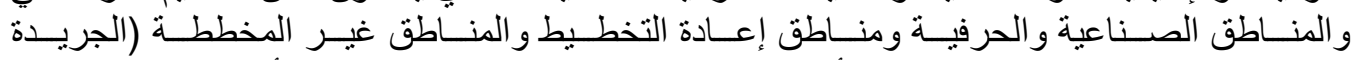

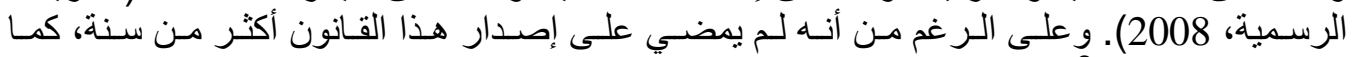

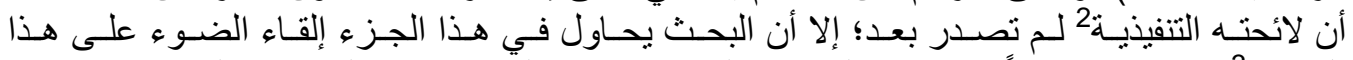

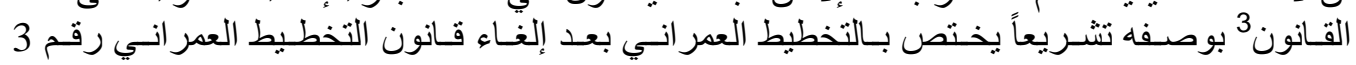

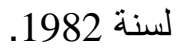

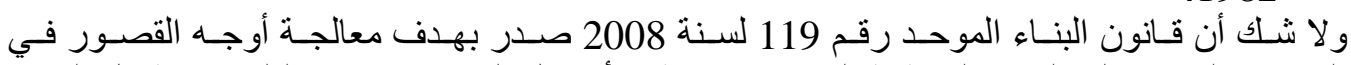

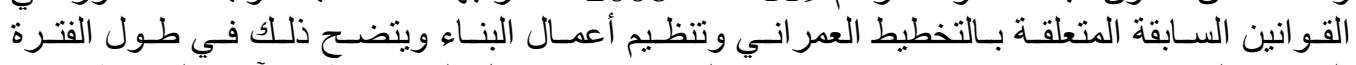

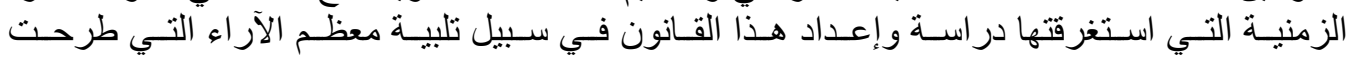

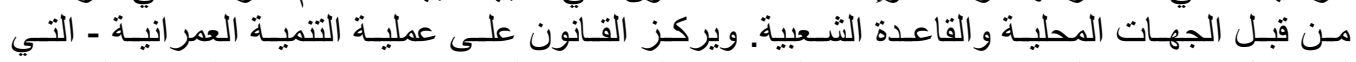

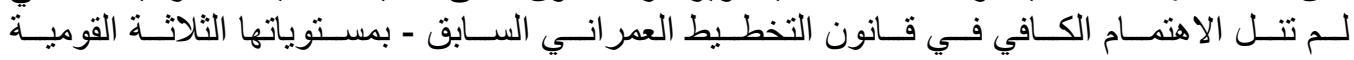

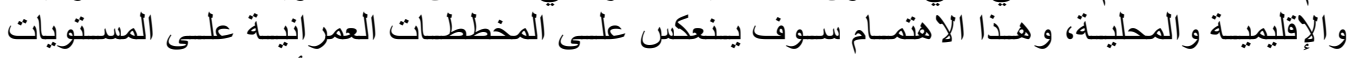

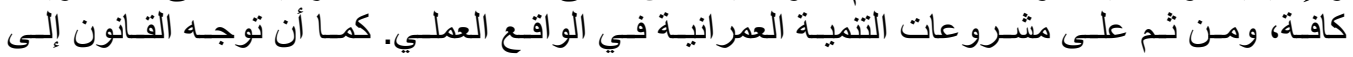

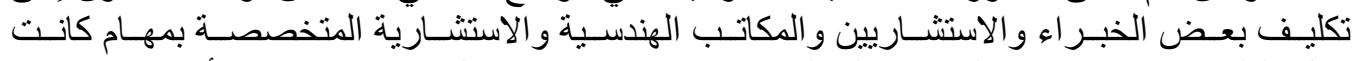

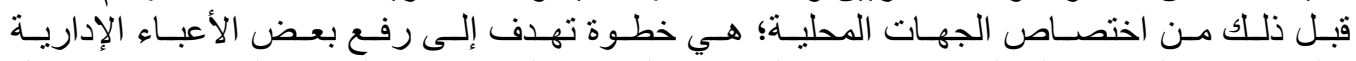

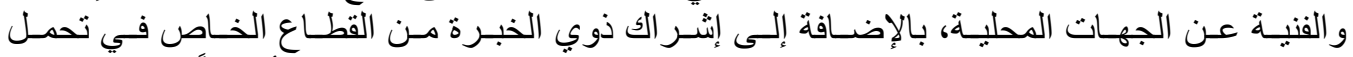

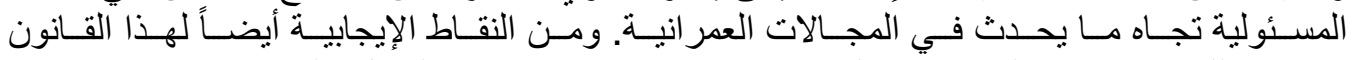

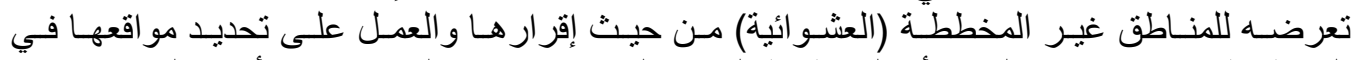

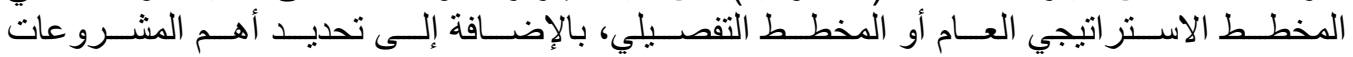

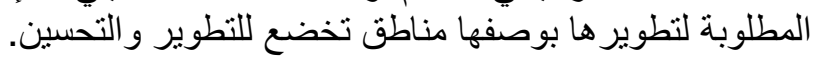

\section{1-4-4 أوجه القصور في قانون البناء الموحد:}

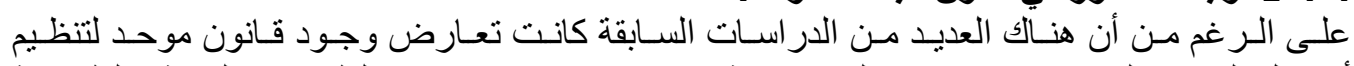

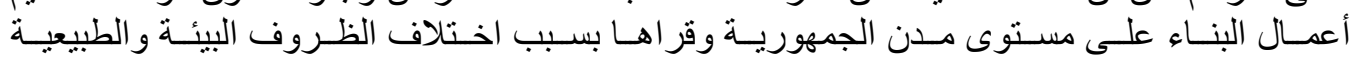

2 اللائحة التنفيذية لهذا القانون ما زالت تحت الدر اسة ولم تصدر حتى الآن على الرغ مث من أن المادة الرابعة من هذا القانون

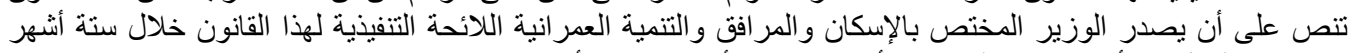

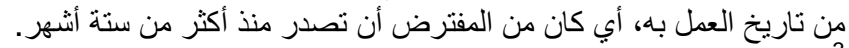

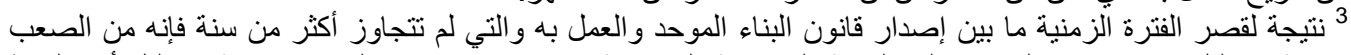

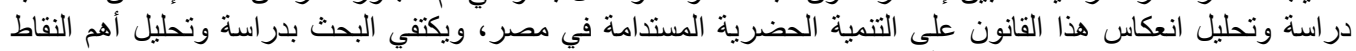
الإيجابية التي احتو اها القانون، وكذلك أوجه القصور التي تعتريه في مجآل التخطيط العمر اني. 


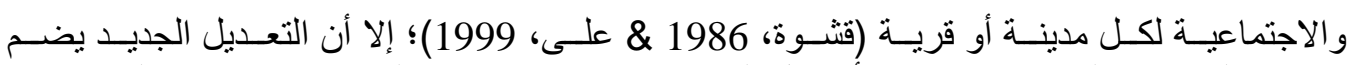

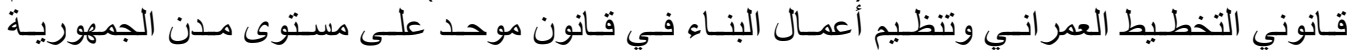

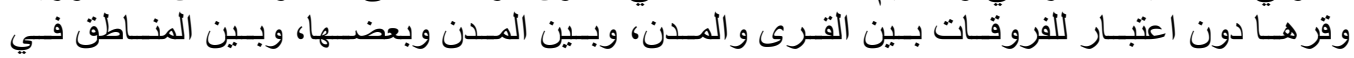

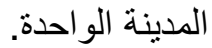

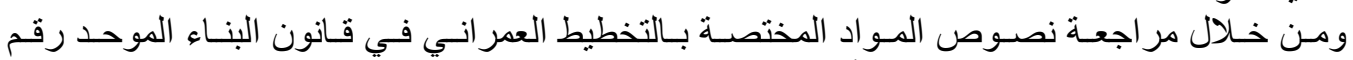

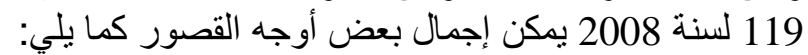

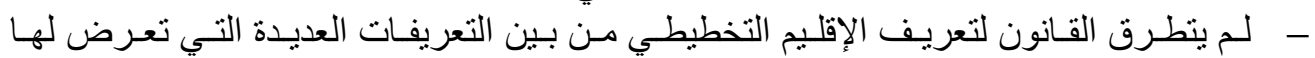

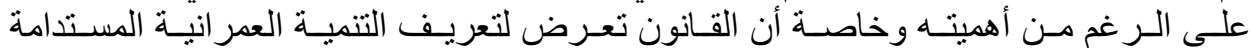

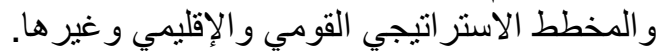

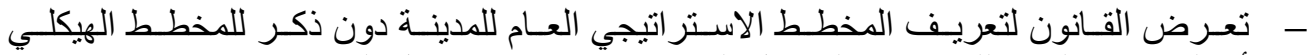

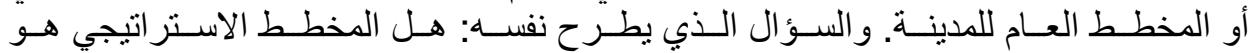

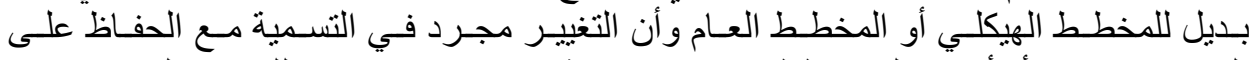

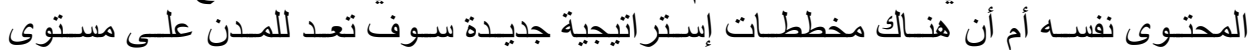

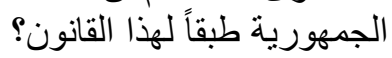

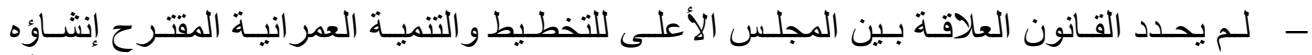

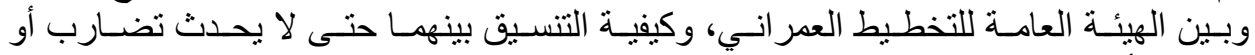
تعارض أو ازدو اجية في وضع السين السياسات و الخطط.

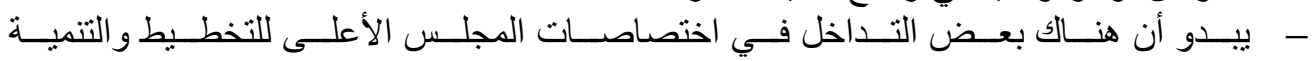

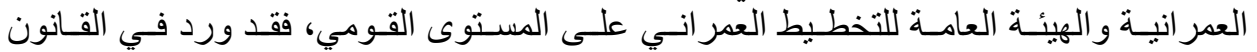

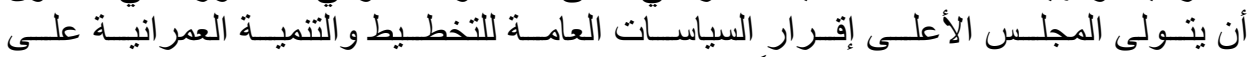

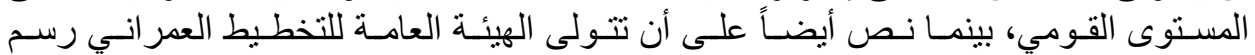

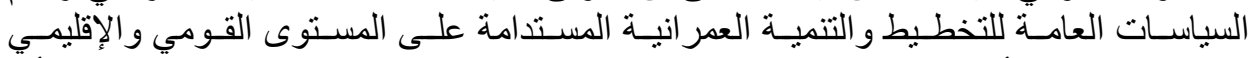

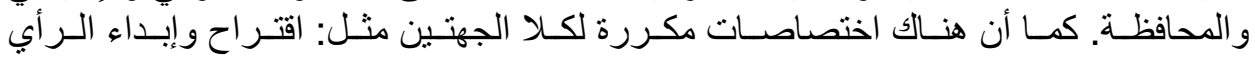
في مشرو عات القو انين ذات العلاقة بات بالتخطيط و التنمية العمر انية.

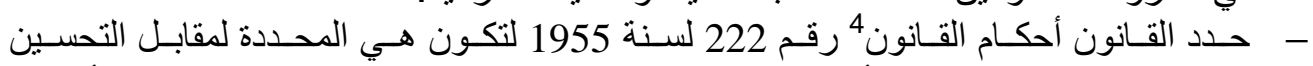

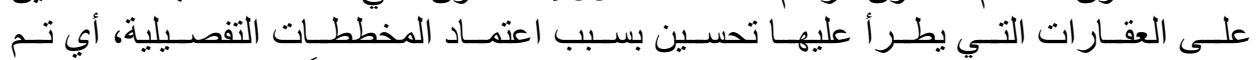
الرجوع إلى أحكام قانون يرجع تاريخ صدورها إلى إلى أكثر من خمسين عاماً.

\section{5. تأثير تشـريعات الإدارة المحلية على التتمية الحضرية المستدامة:}

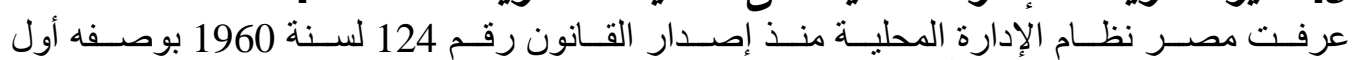

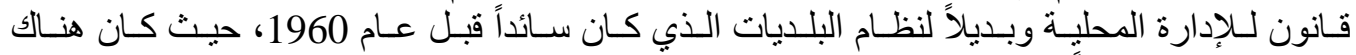

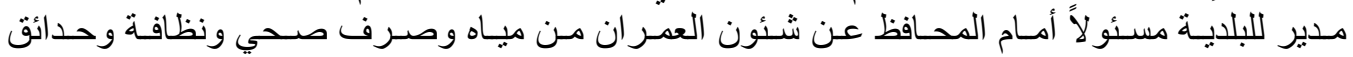

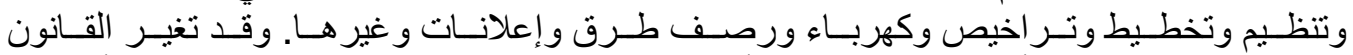

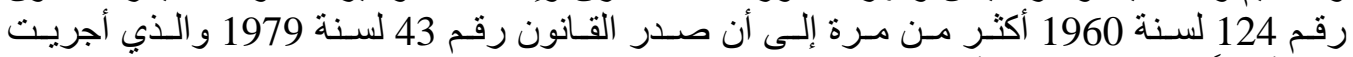
عليه أيضاً عدة تعديلات إلا أنه ما زال ساري المفعول النهول حتى الآن (علام، 1986).

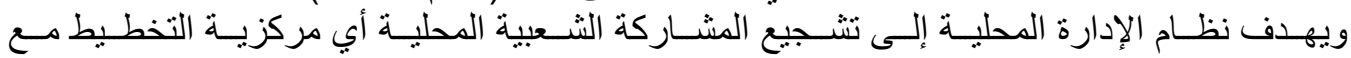

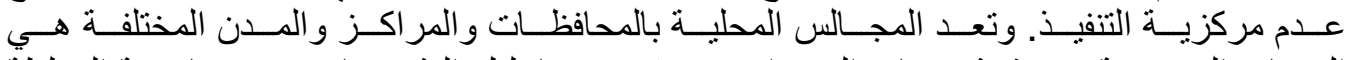

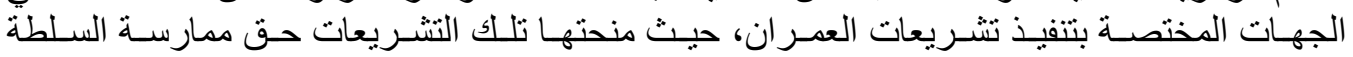

4 القانون رقم 222 لسنة 1955 يختص بفرض مقابل تحسين على العقار ات التي يطر أ عليها تحسين بسبب المنفعة العامة. 


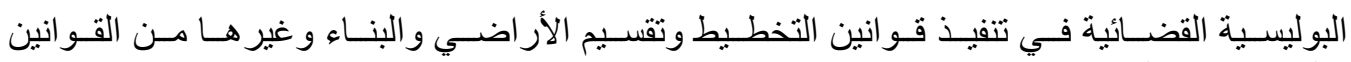

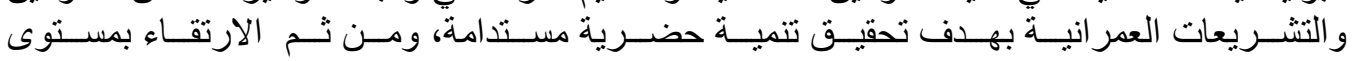

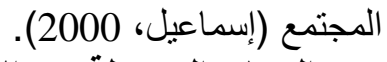

\section{1-5 الجهات المسئولة عن الإدارة المحلية:}

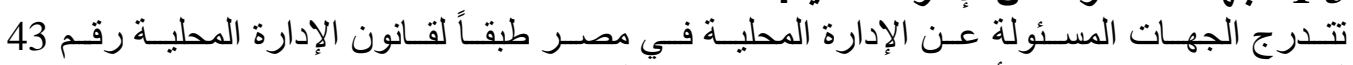

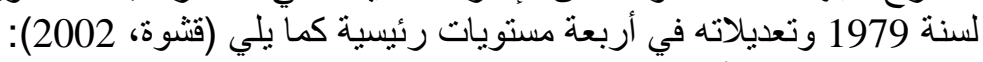

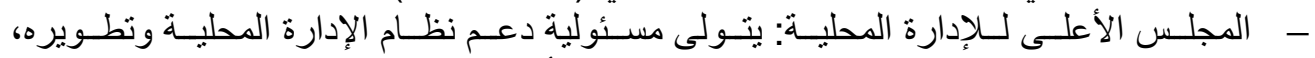

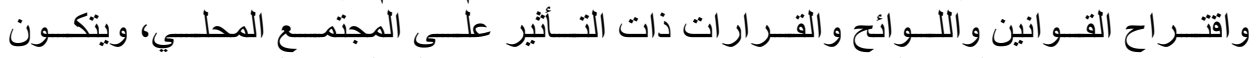

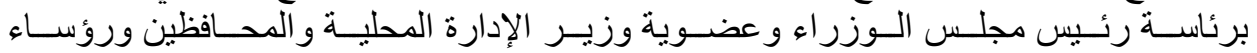
المجالس الثعبية المحلية للمحافظات.

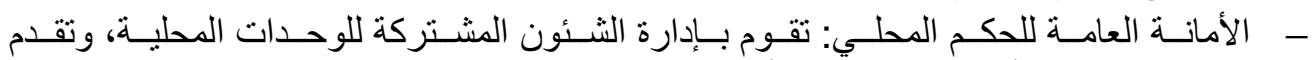

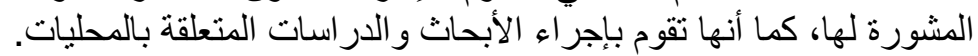

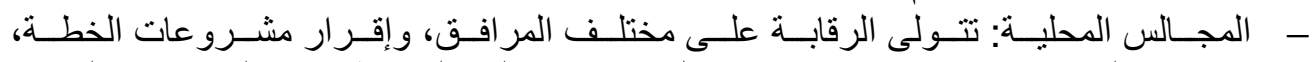

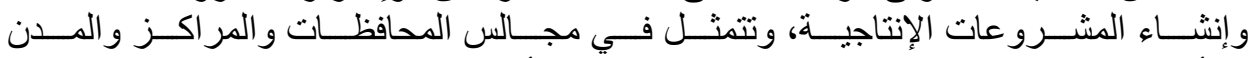

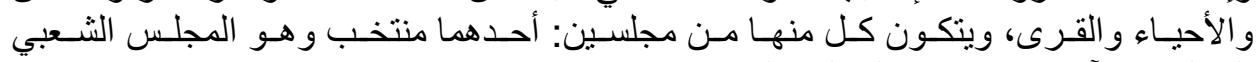
المحلي، و الآخر معين و ولئو المجلس التنفيذي.

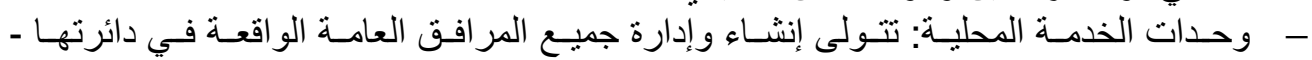

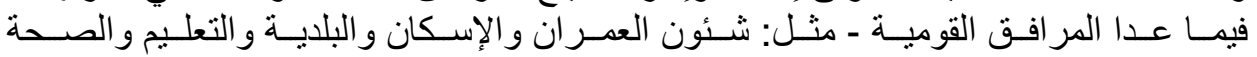
و ألزر اعة و الصناعة و المو أصلات و غير ها.

2-5 دور الإدارة المحلية في عملية التنمية الحضرية المستدامة:

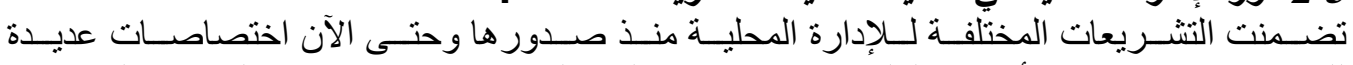

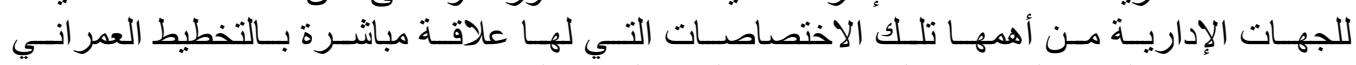

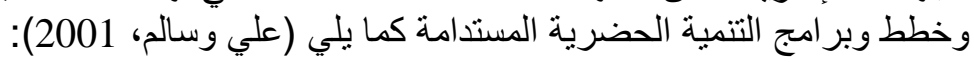

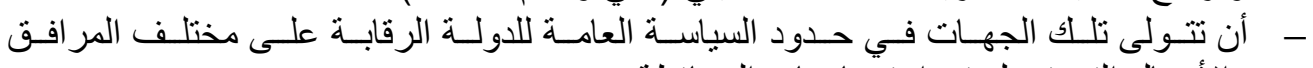

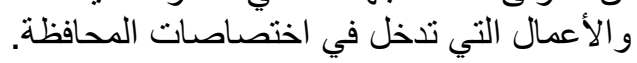

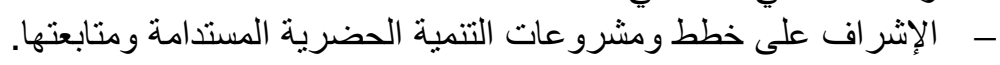

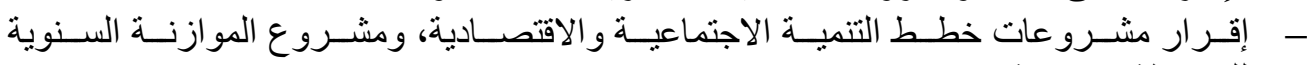
لل لمحافظة، ومتابعة تنفيذها.

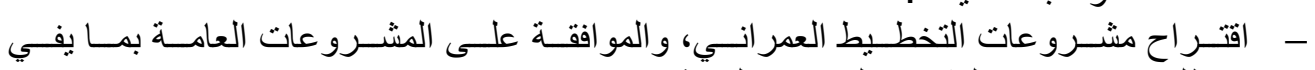

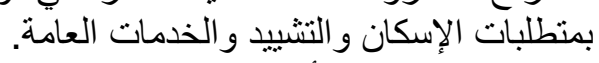

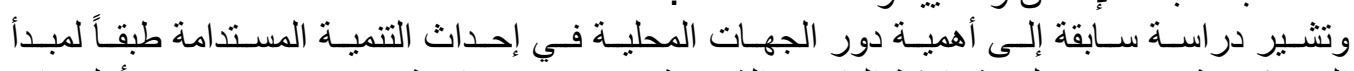

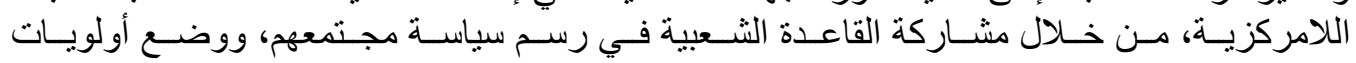

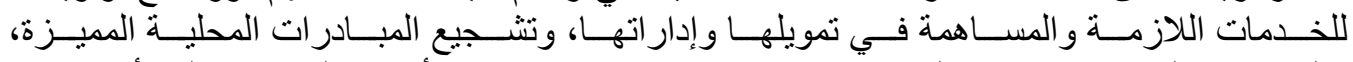

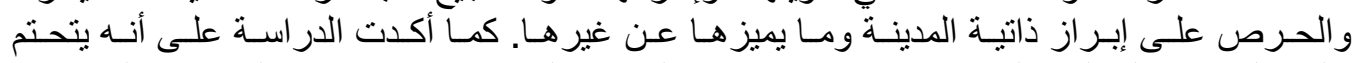

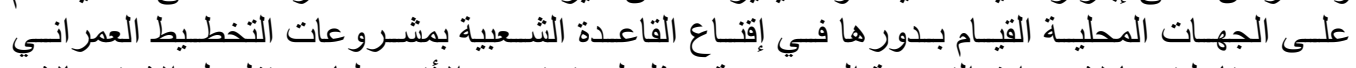

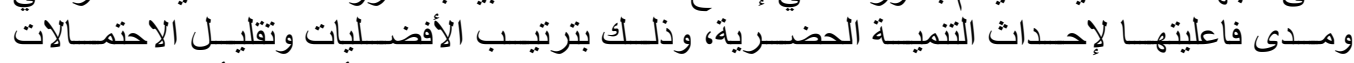

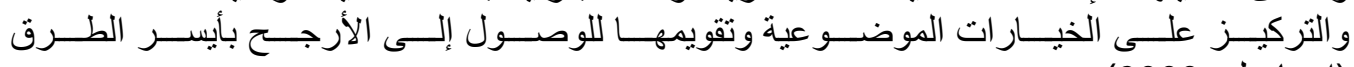
(إسماعيل، 2000). 


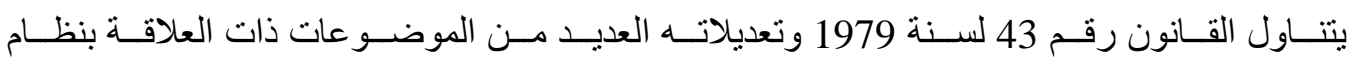

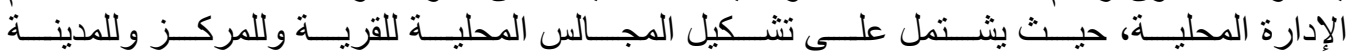

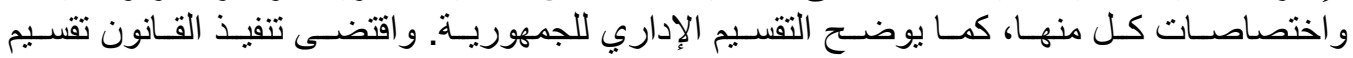

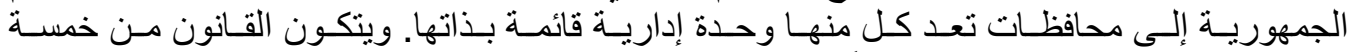

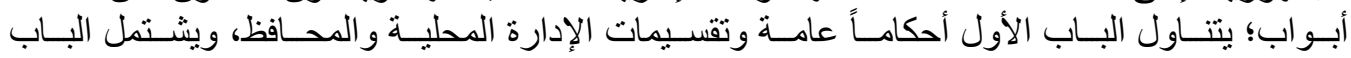

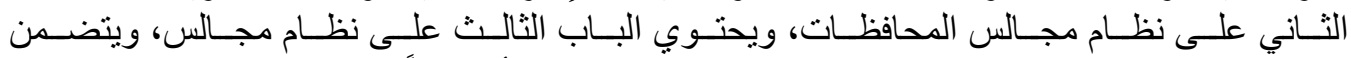

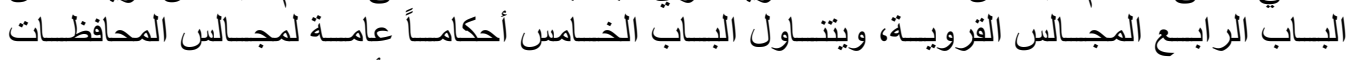

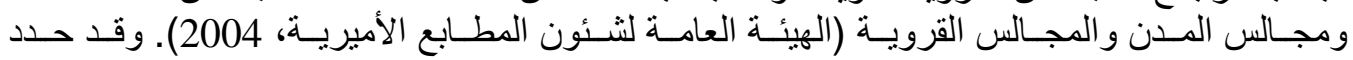

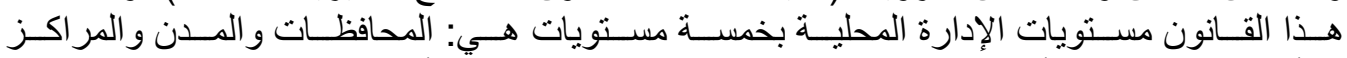

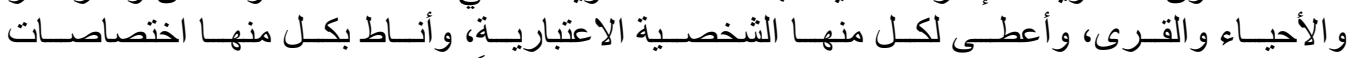

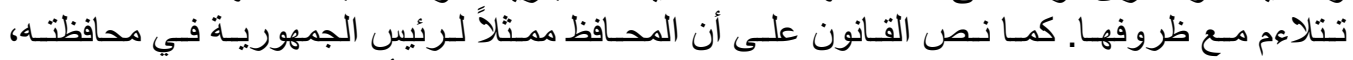

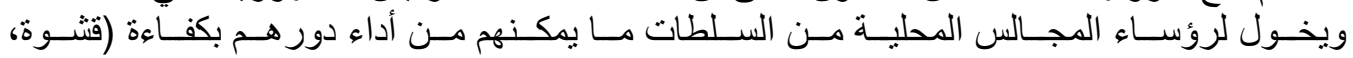

. (2002

\section{1-3-5 أوجه القصور في قانون الإدارة المحلية:}

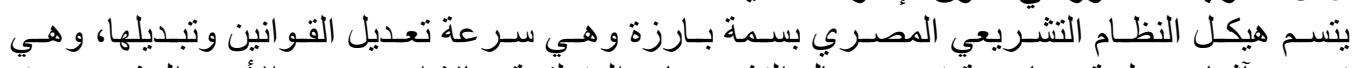

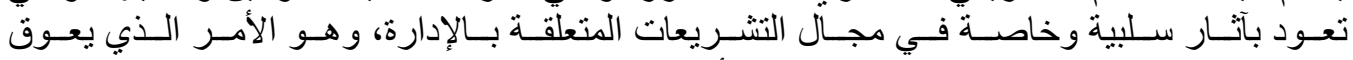

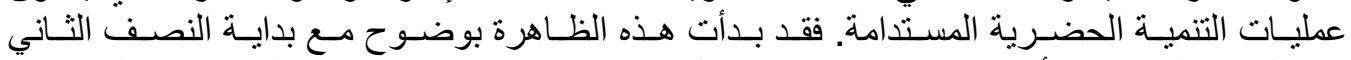

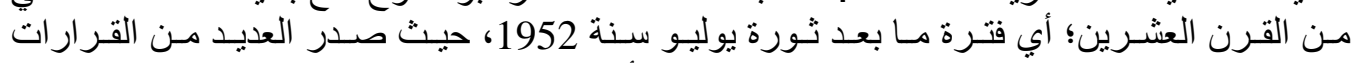

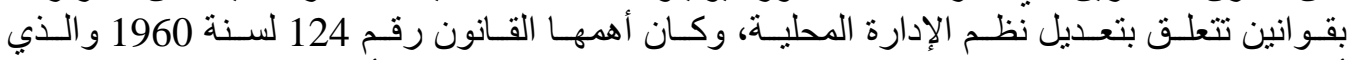

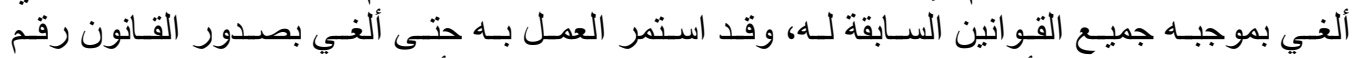

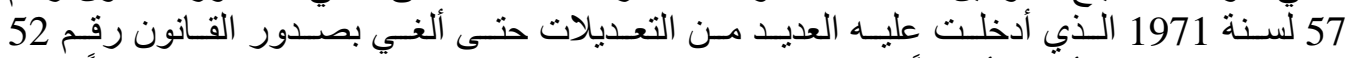

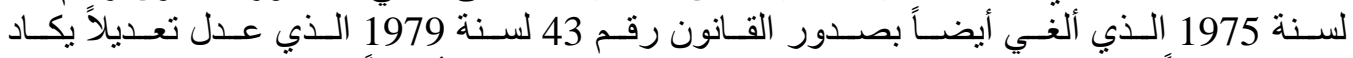

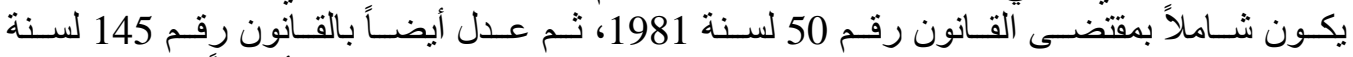

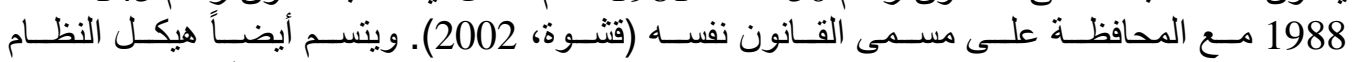

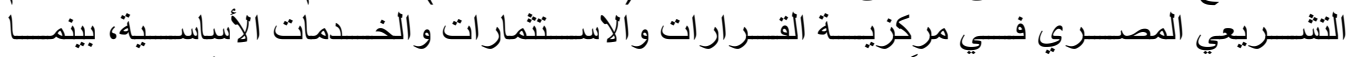

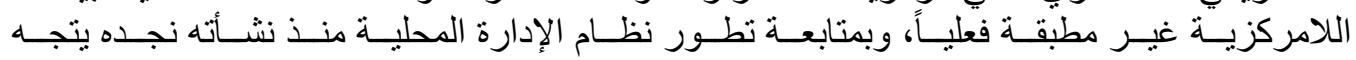

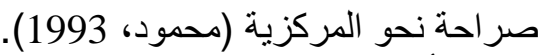

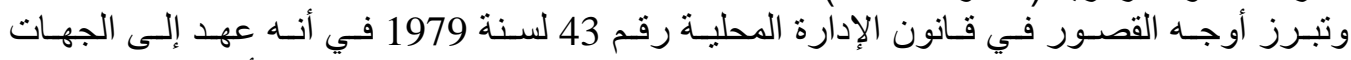

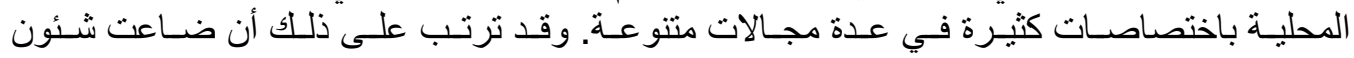

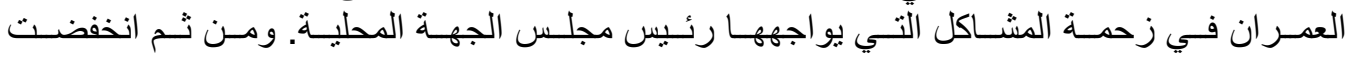

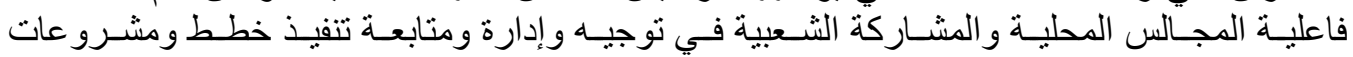

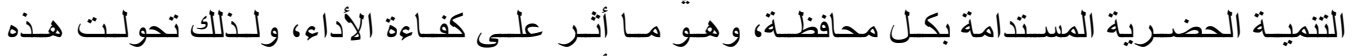

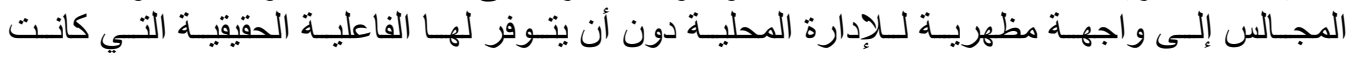

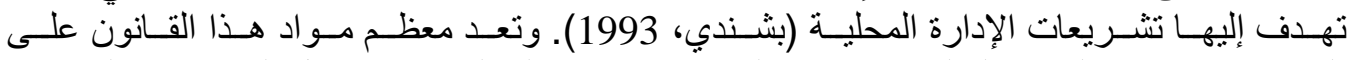

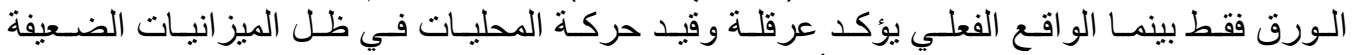

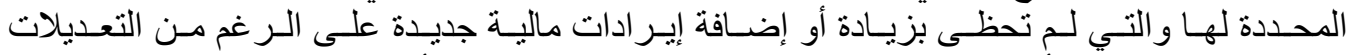

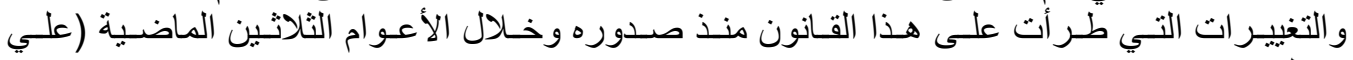

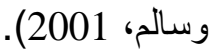

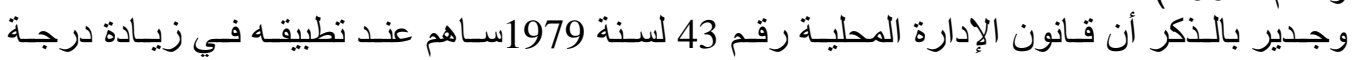

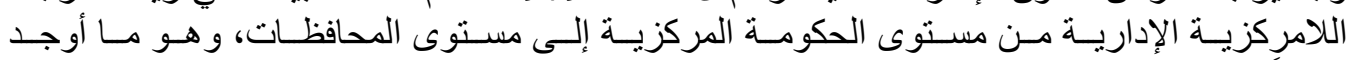

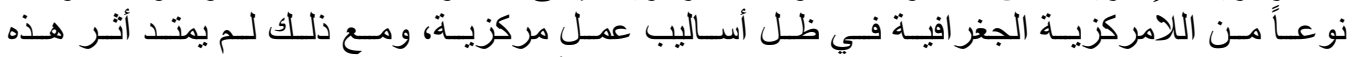

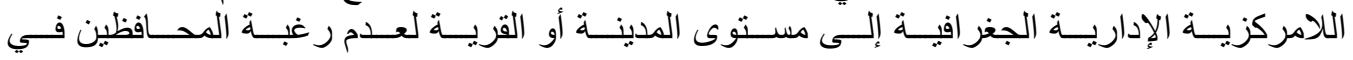




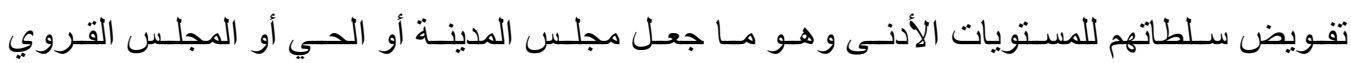

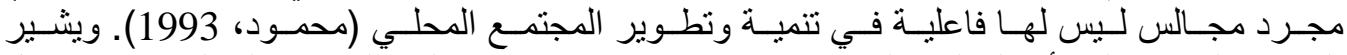

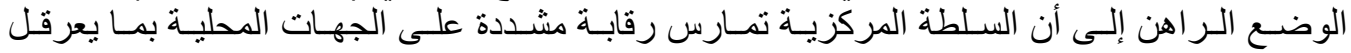

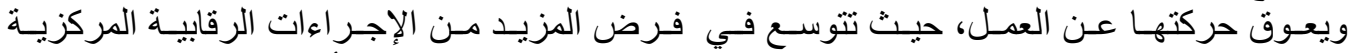

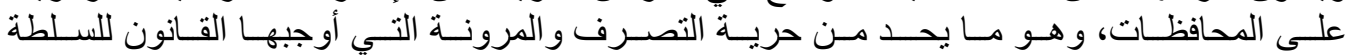

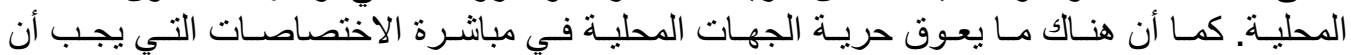

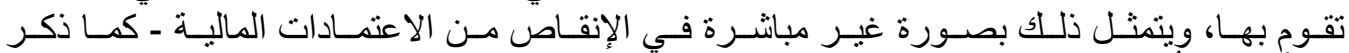

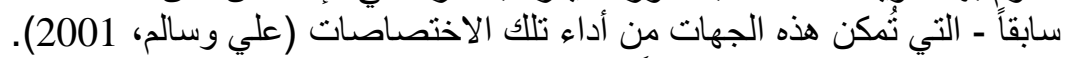

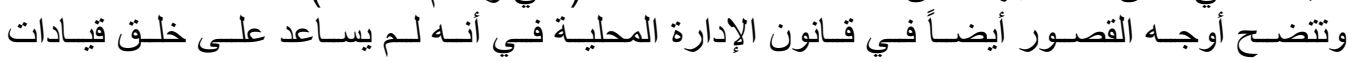

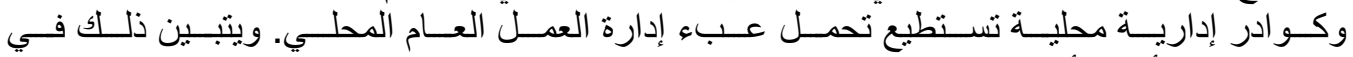

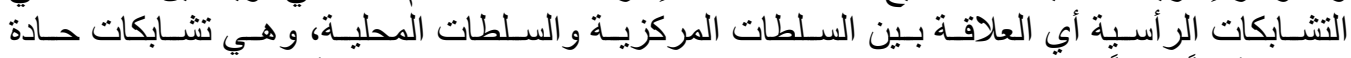

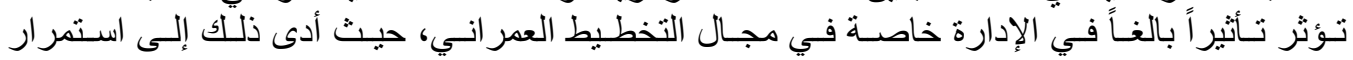

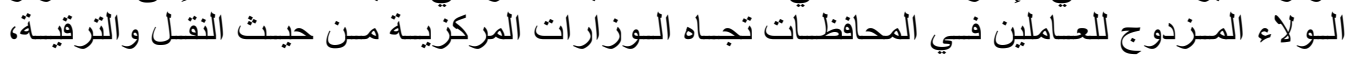

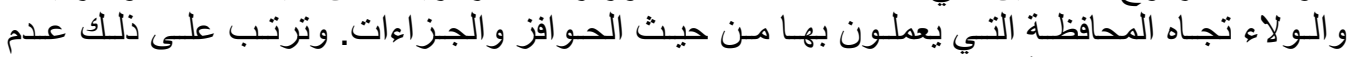

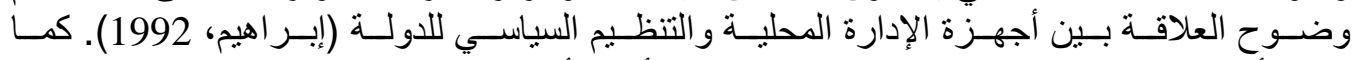

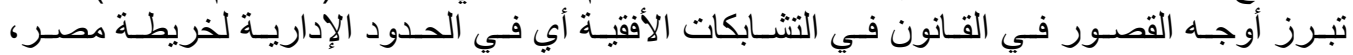

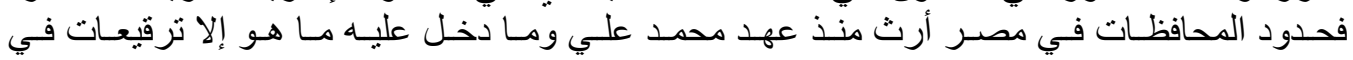

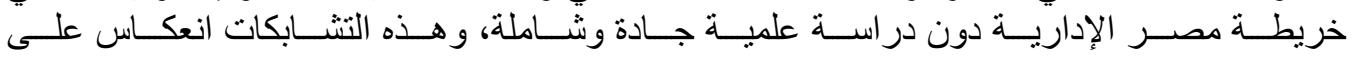

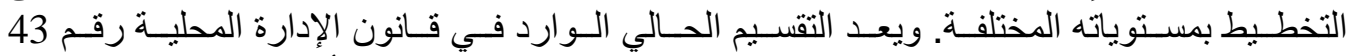

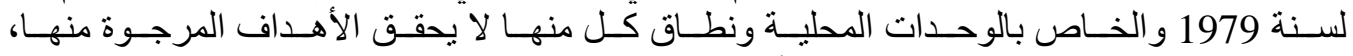

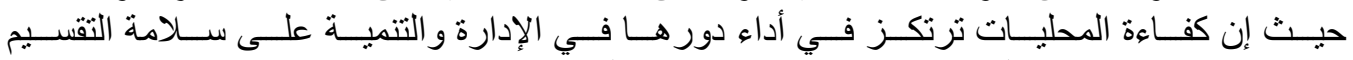

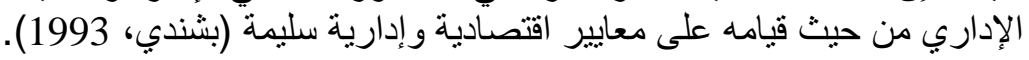

\section{2-3-5 انعكاس القصور في قانون الإدارة المحلية على التنمية الحضرية المستدامة:}

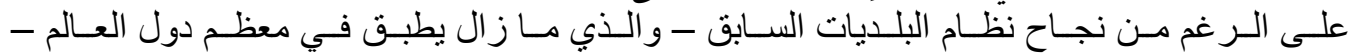

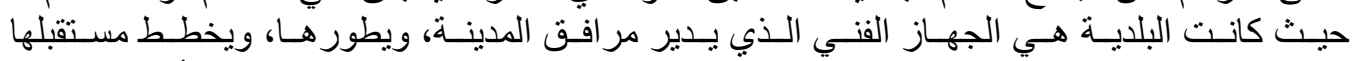

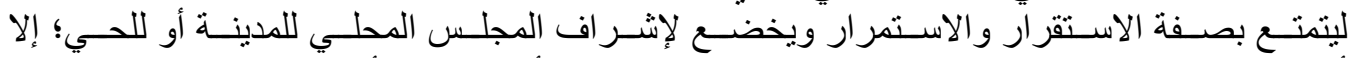

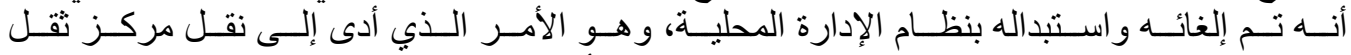

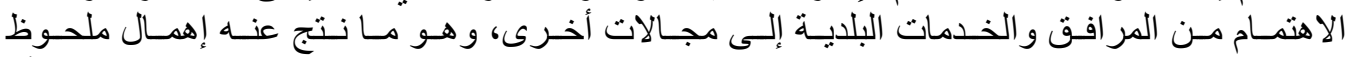

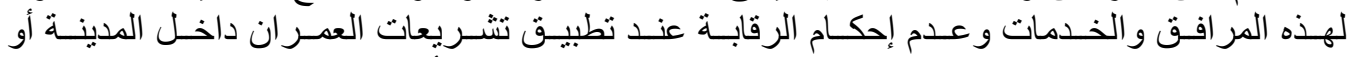

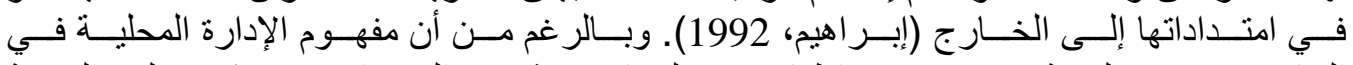

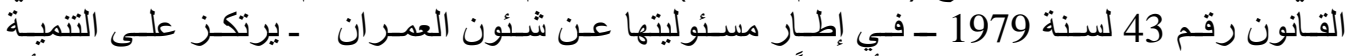

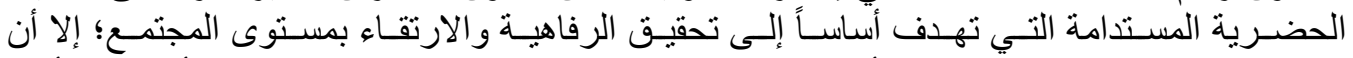

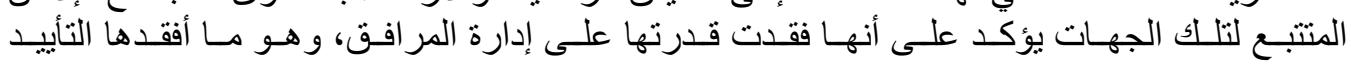

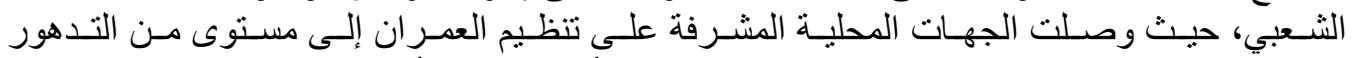

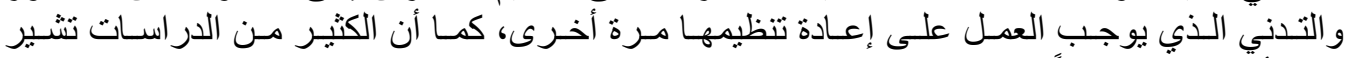

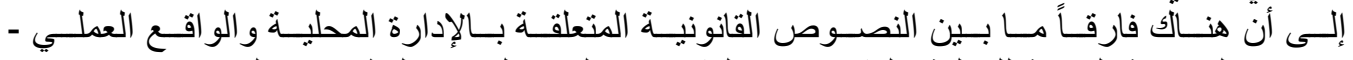

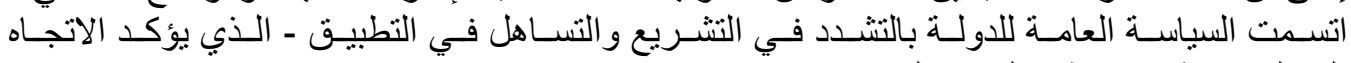

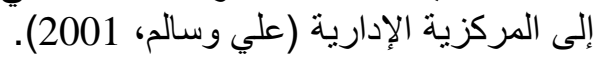

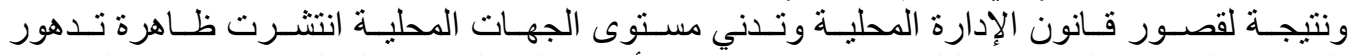

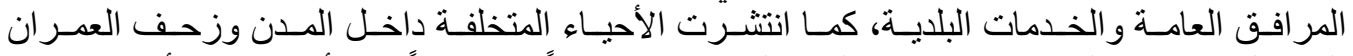

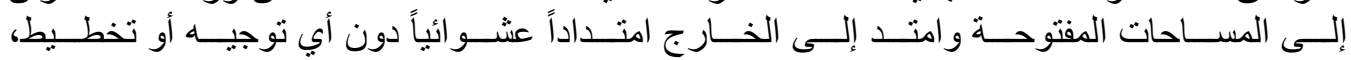




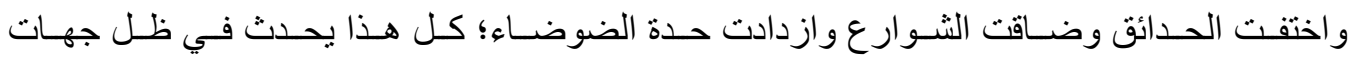

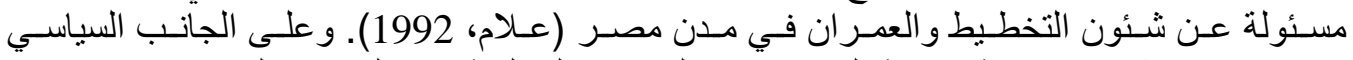

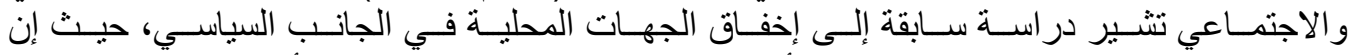

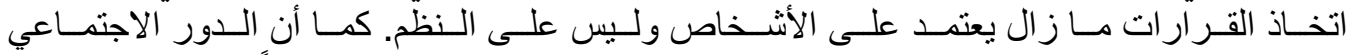

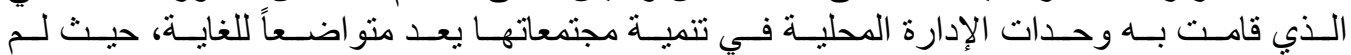

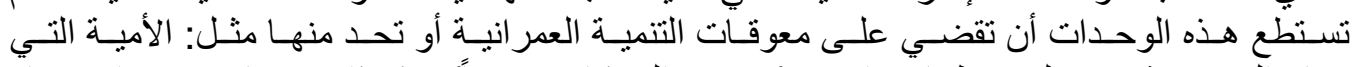

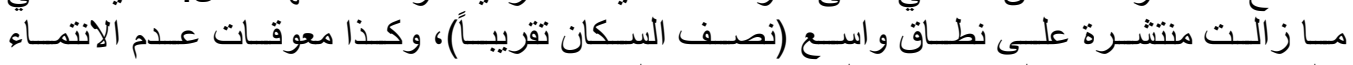

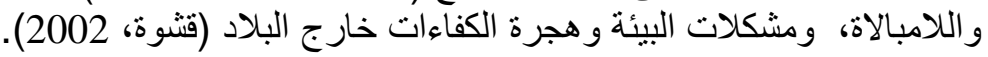

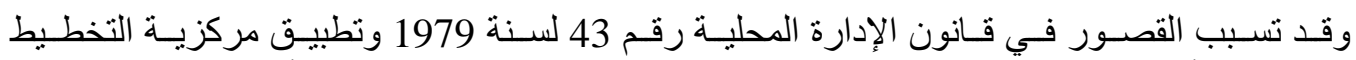

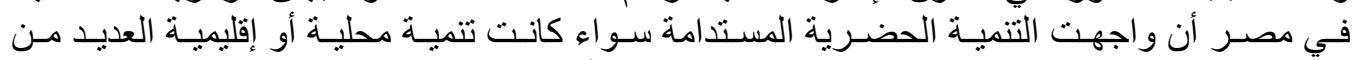

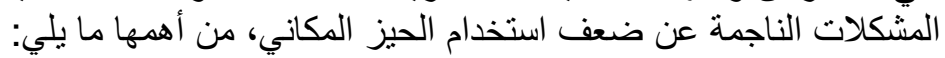

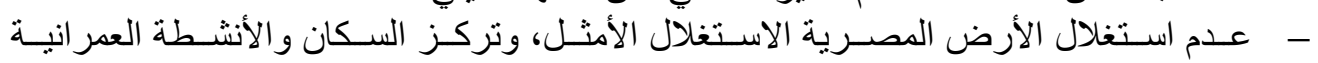

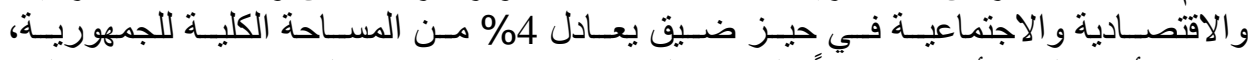

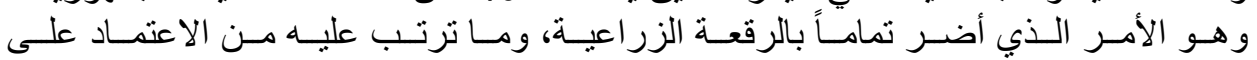

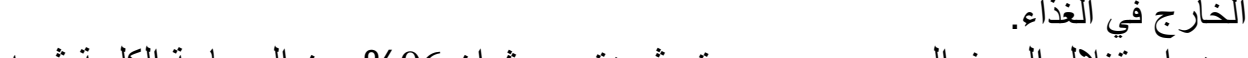

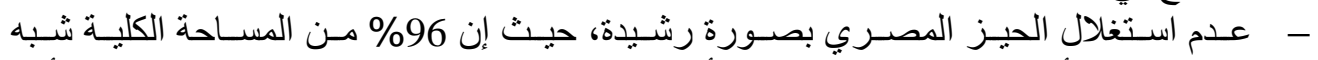

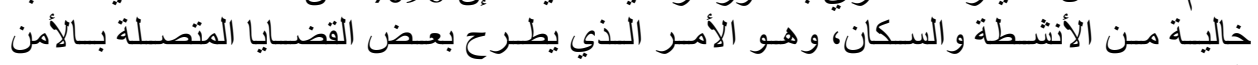
القومي (قتشوه، 2002).

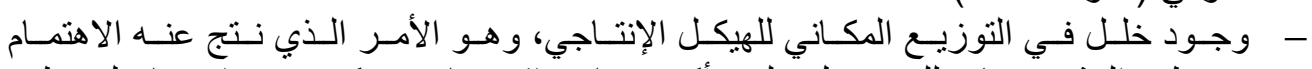

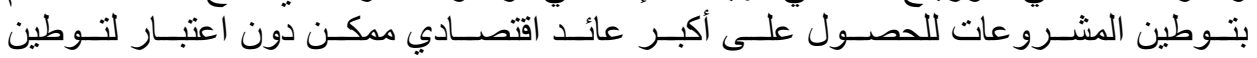
هذه المشرو عات لخدمة التنمية العمر انية و الاقتصادية وليت والاجتماعية على على المدى البع البعيد.

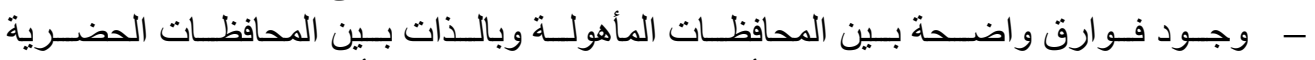

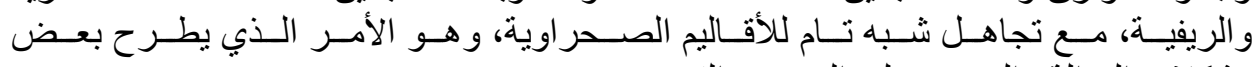

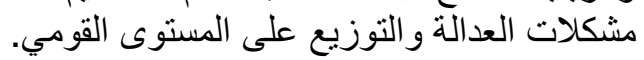

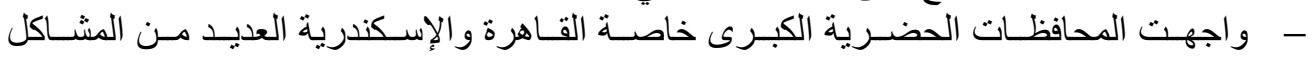

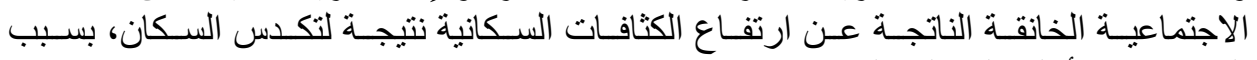

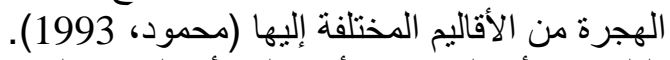

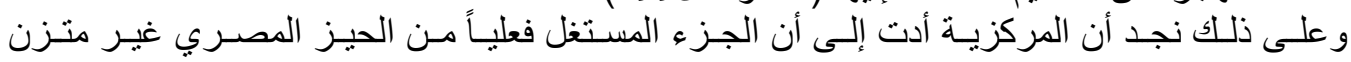

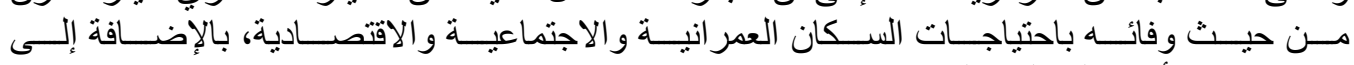

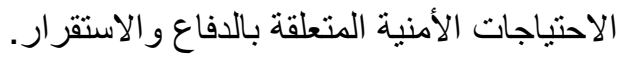

الخلاصة:

يمكن إجمال خلاصة البحث في النقاط التالية:

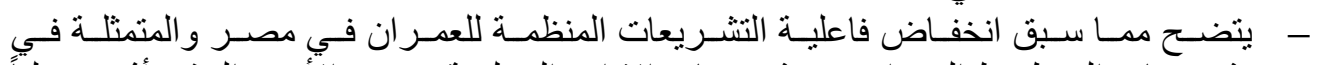

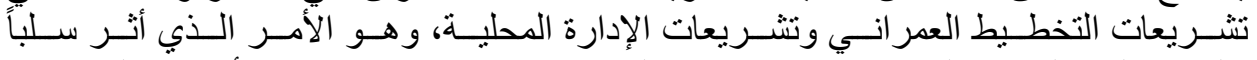

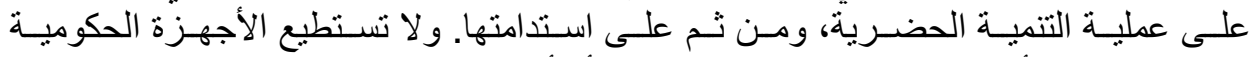

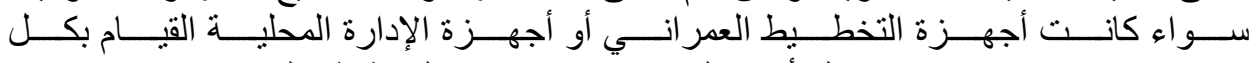

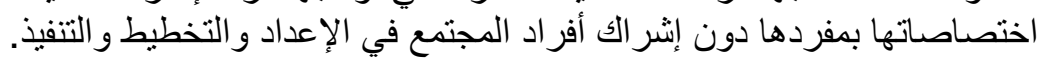

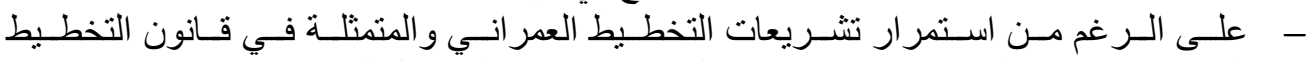

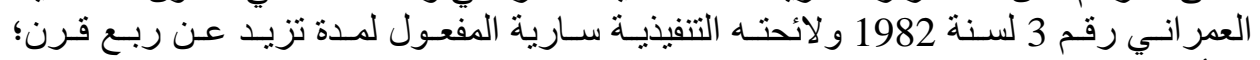

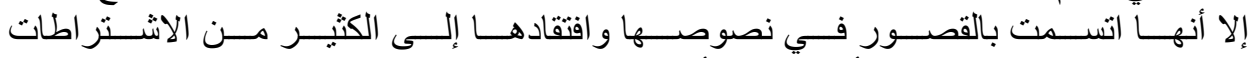

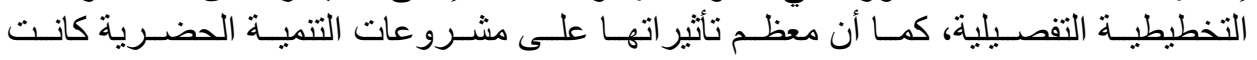




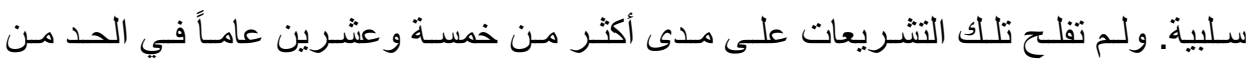

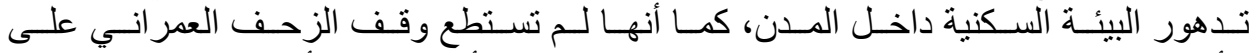

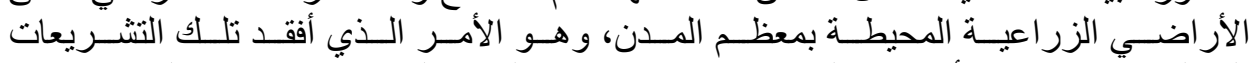

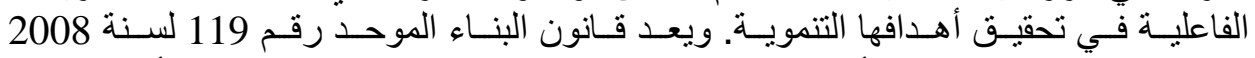

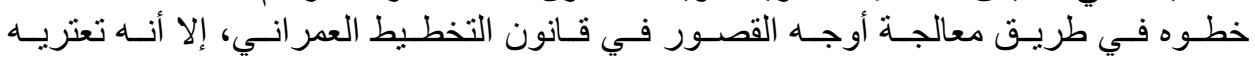

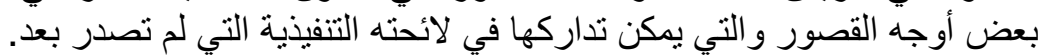

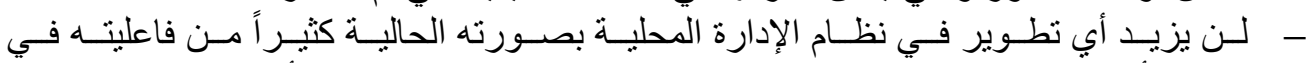

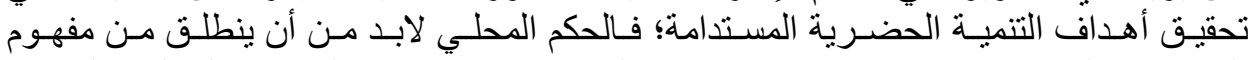

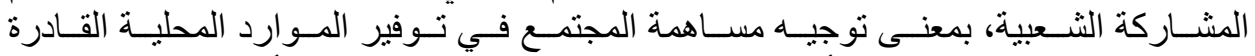

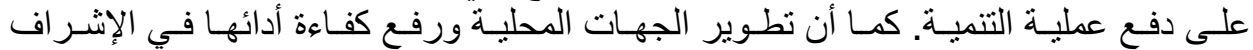

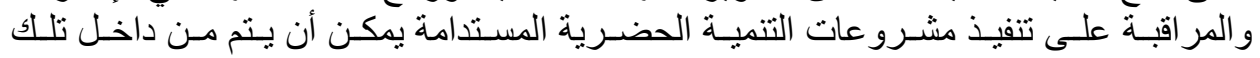

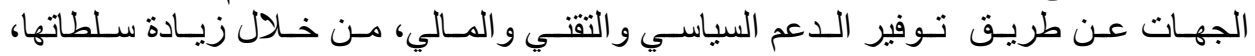

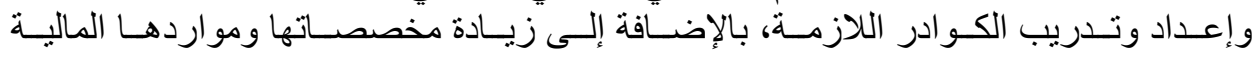
التي تدعم نفوذها السياسي.

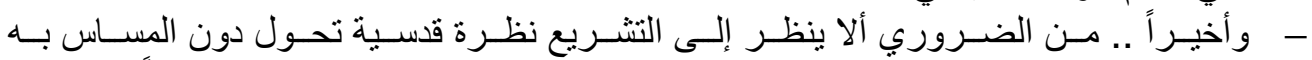

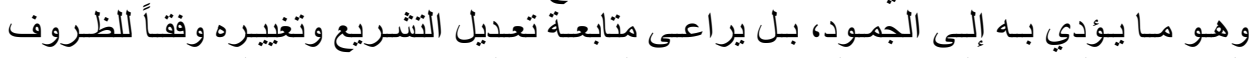

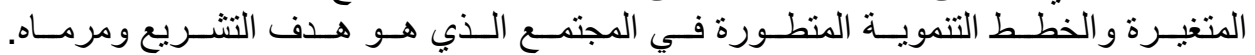

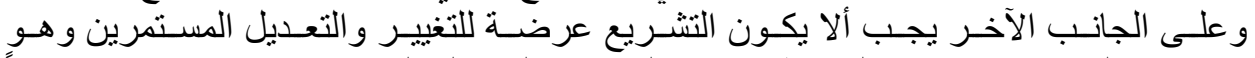

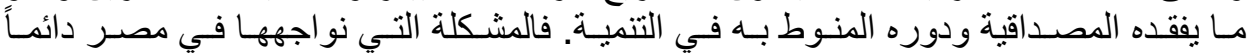

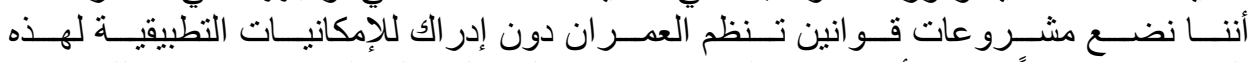

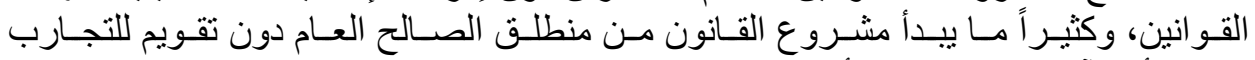

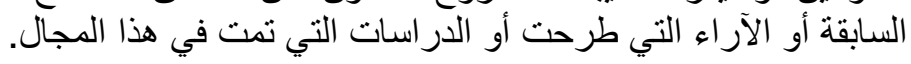

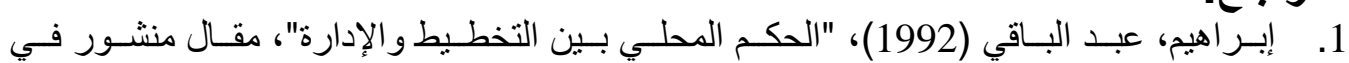
جريدة الأهر ام الاقتصنادي، تاريخ (192)، 30 مارس، القاهرة.

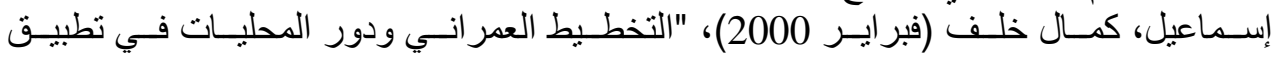

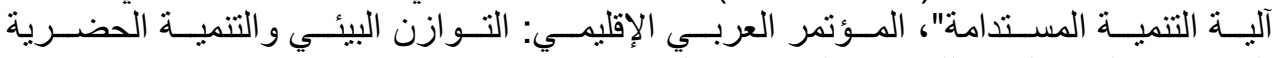

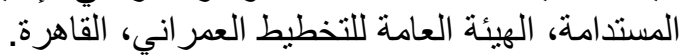

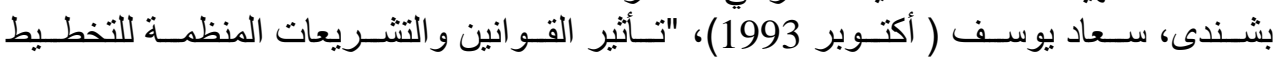

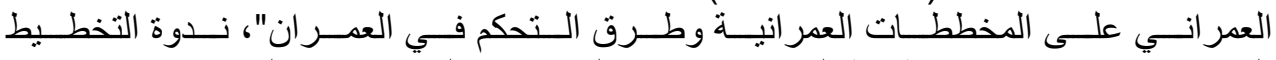

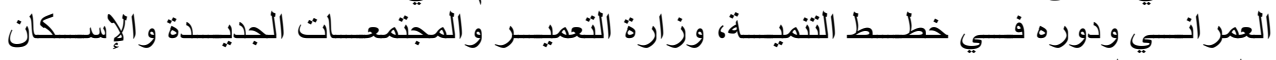

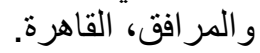

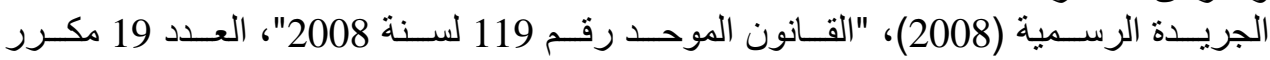
.4

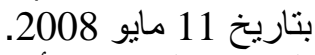

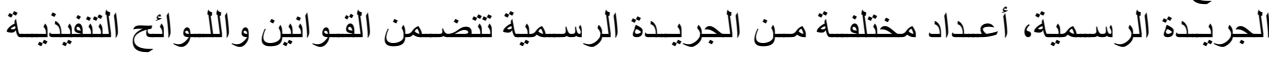
ذات العلاقة بالتشريعات المنظمة للعمر ان في مصر التر ، القاهرة.

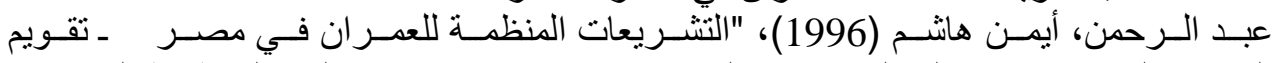

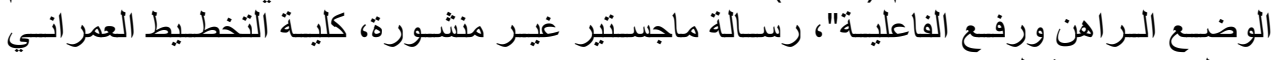
و الإقليمي، جامعة القاهرة.

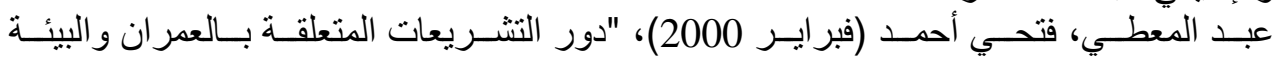

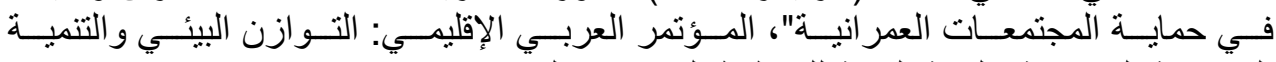

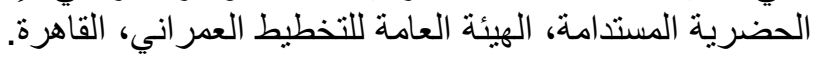




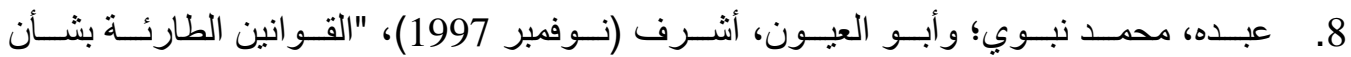

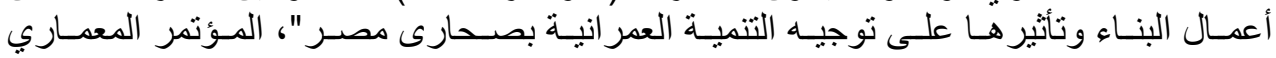

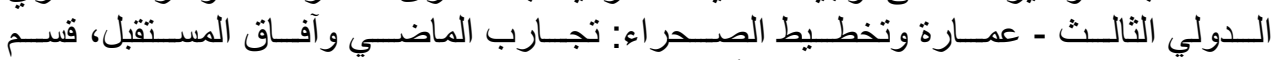
الهندسة المعمارية، كلية الهندسة، جامعة الفيطة أسيوط.

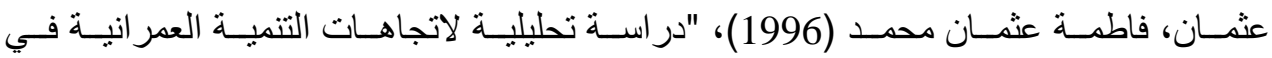

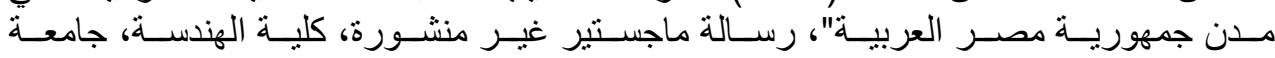
أسيوط.

10. علام، أحمد خالد (1986)، "التشريعات المنظمة للعمر ان"، مكتبة الأنجلو، القاهرة.

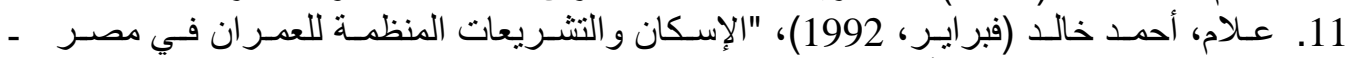

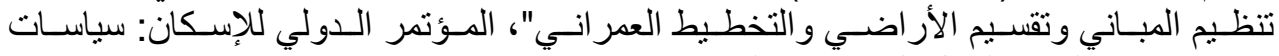
ونظم الإسكان لذوي الدخل المنخفض، القاهرة.

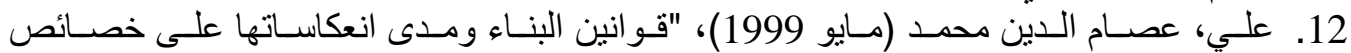

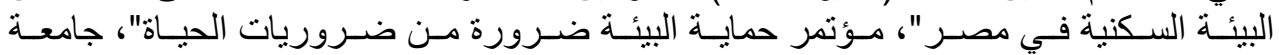

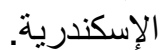

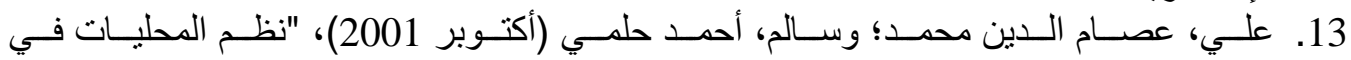

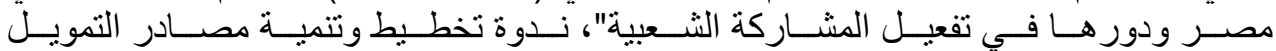

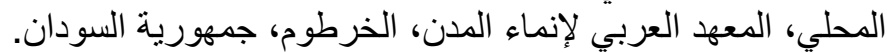

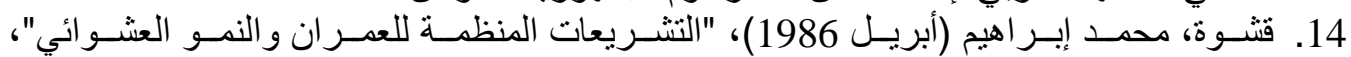

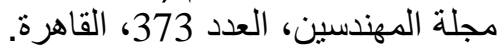

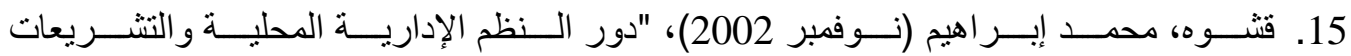

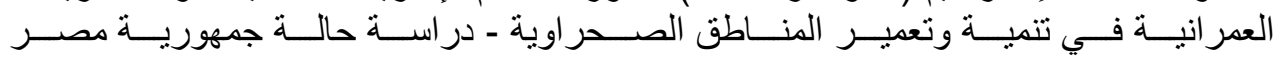

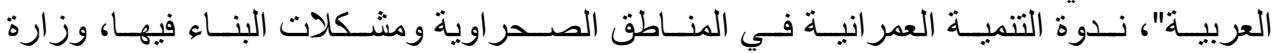

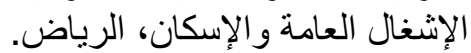

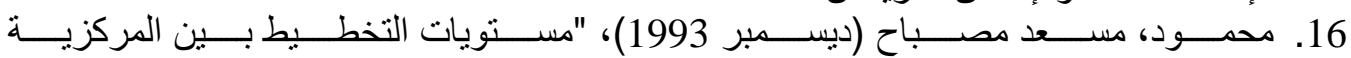

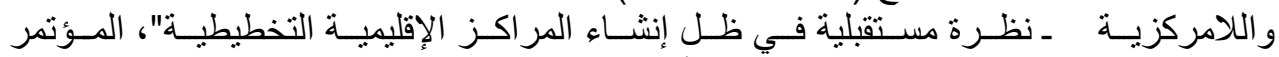

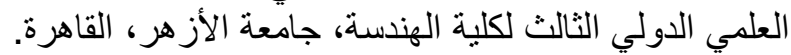

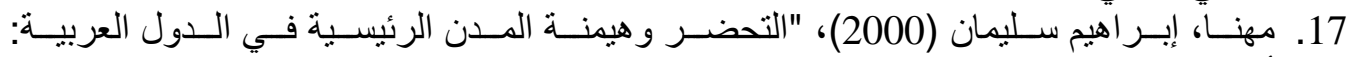

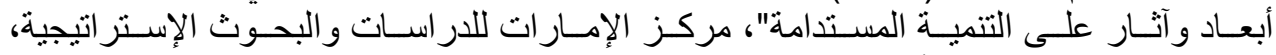

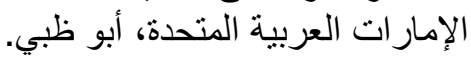

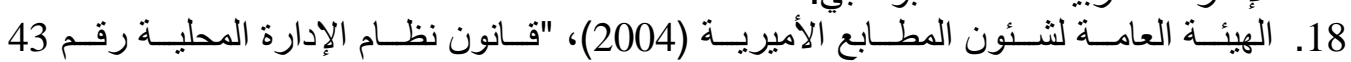
لسنة 1979م ومذكرته الإيضاحية و لائحته التنفيذية"، القاهرة.

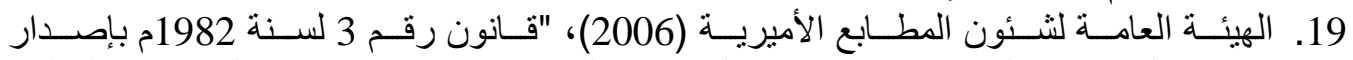

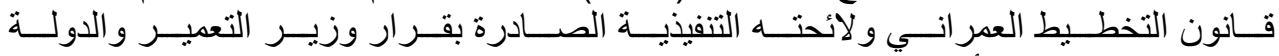

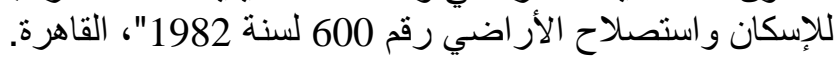

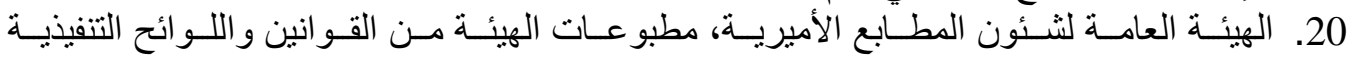

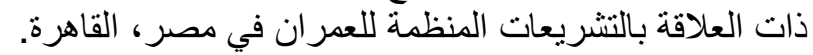

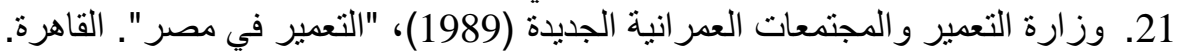
22. Ali, Mohamed, Esam Al-Din (1998), "Urban Planning Laws and Building Regulations in Egypt: District Codes as an Approach to Improve the Quality of the Residential Environment", Ph.D. Dissertation, Faculty of Engineering, Assiut University, Egypt. 
23. Listokin, David \& Walker, Carole (1989), "The Subdivision and Site Plan Handbook", Center for Urban Policy Research, New Jersey, USA.

24. Muschett, F. Douglas (1997), "Principles of Sustainable Development", Saint Lucie Press, a Division of CRC Press, Florida, USA.

25. World Commission on Environment and Development (WCED) (1987), "Our Common Future", Oxford University Press, Oxford, UK.

26. Zeijl-Rozema, V. Annemarie and Others (2008), "Governance for Sustainable Development: A Framework", John wiley \& Sons, Ltd and ERP Environment, Netherlands. 